\title{
A Systematic Review of Air Quality Sensors, Guidelines, and Measurement Studies for Indoor Air Quality Management
}

\author{
He Zhang * and Ravi Srinivasan \\ UrbSys (Urban Building Energy, Sensing, Controls, Big Data Analysis, and Visualization) Laboratory, \\ M.E. Rinker, Sr. School of Construction Management, University of Florida, Gainesville, FL 32603, USA; \\ sravi@ufl.edu \\ * Correspondence: rupta00@ufl.edu
}

Received: 29 September 2020; Accepted: 27 October 2020; Published: 30 October 2020

\begin{abstract}
The existence of indoor air pollutants—such as ozone, carbon monoxide, carbon dioxide, sulfur dioxide, nitrogen dioxide, particulate matter, and total volatile organic compounds-is evidently a critical issue for human health. Over the past decade, various international agencies have continually refined and updated the quantitative air quality guidelines and standards in order to meet the requirements for indoor air quality management. This paper first provides a systematic review of the existing air quality guidelines and standards implemented by different agencies, which include the Ambient Air Quality Standards (NAAQS); the World Health Organization (WHO); the Occupational Safety and Health Administration (OSHA); the American Conference of Governmental Industrial Hygienists (ACGIH); the American Society of Heating, Refrigerating and Air-Conditioning Engineers (ASHRAE); the National Institute for Occupational Safety and Health (NIOSH); and the California ambient air quality standards (CAAQS). It then adds to this by providing a state-of-art review of the existing low-cost air quality sensor (LCAQS) technologies, and analyzes the corresponding specifications, such as the typical detection range, measurement tolerance or repeatability, data resolution, response time, supply current, and market price. Finally, it briefly reviews a sequence (array) of field measurement studies, which focuses on the technical measurement characteristics and their data analysis approaches.
\end{abstract}

Keywords: indoor air quality; standards; guidelines; pollutants; sick building syndrome; low-cost sensor

\section{Introduction}

The WHO reported that poor air quality caused 4.2 million deaths in 2016, of which, primarily, $17 \%$ were due to strokes, $25 \%$ were due to COPD, and $26 \%$ were due to respiratory disease [1]. It is evident from many studies that the concentration levels of indoor air pollutants are two to four times higher than those of outdoor air pollutants [2-5]. In the U.S., on average, people spend $22.25 \mathrm{~h}$ per day inside buildings, and $1.44 \mathrm{~h}$ in cars or other transportation modes [6,7]. With higher concentrations of pollutants inside buildings, IAQ is one of the world's highest environmental health risks [8,9], which cannot be ignored.

The impact on human health owing to the indoor environment is, broadly speaking, either BRI or SBS. BRI relates to symptoms that are clinically defined, which are diagnosed with directly airborne building contaminants [5-8]. On the other hand, SBS is a collection of symptoms for which the cause is unclear [10-12]. It is to be noted that SBS is a consequence of poor indoor air quality [13]. Besides this, the symptoms caused by psychological illnesses—such as headaches, fatigue, nausea, hyperventilation, and fainting — are referred to as Mass Psychogenic Illness (MPI) [14]. Building-associated illnesses 
not only cause symptoms, but can also cause an enormous economic loss. In the U.S., SBS affects 10 to 25 million people, and results in an estimated $\$ 82$ billion to $\$ 104$ billion loss every year, owing to productivity loss [15-19]. The US EPA estimated a \$140 billion annual direct medical expenditure related to IAQ problems $[20,21]$.

SBS has become a widely-studied subject in recent years; the following health manifestations have been identified by medical studies: anxiety, depression, environmental discomfort and job strain (psychological symptoms); asthma, allergies, malaise, headache, throat dryness, coughs, sputum, ocular issues, rhinitis, wheezing, skin dryness, and eye pain (physical symptoms/psychosomatic symptoms) [22-24]. Klas et al. [25] found that SBS is related to temperature, air intake, building dampness, exposure to static electricity, indoor smoke, noise, and the building's age. In addition, the level of physical response is related to age, employment duration, asthma symptoms, and psychological states.

The contributors of SBS and BRI can be divided into four categories: (1) physical (e.g., temperature, humidity, ventilation, illuminance, noise, air quality, etc.); (2) biological; (3) chemical (e.g., radioactive substances, MVOCS, formaldehyde, plasticizer, fine dust, etc.) concentrations; (4) psychosocial and individual traits (e.g., gender, age, atopy, hereditary disease, smoking, psychological state, etc.) [26-28]. The indoor thermal comfort criteria were recommended by the ASHRAE Standard 55-2017, which specifies an indoor operative temperature between $68.5^{\circ} \mathrm{F}$ and $75^{\circ} \mathrm{F}$ in the winter, and between $75^{\circ} \mathrm{F}$ and $80.5^{\circ} \mathrm{F}$ in the summer [29]. Similarly, the recommended indoor relative humidity given by the by US EPA is between $30 \%$ and $60 \%$, in order to reduce mold growth [30].

The presence of indoor air pollutants is a major factor that directly affects human health [31]. Indoor air pollutants may include $\mathrm{O}_{3}, \mathrm{CO}, \mathrm{CO}_{2}, \mathrm{SO}_{2}, \mathrm{NO}_{2}$, particulate matter (PM), and TVOC, which can cause tiredness, Acute Respiratory Infections (ARI), COPD, and lung cancer [28,32].

\section{Indoor Air Quality, the Vulnerable Population, and Asthma}

A 2015 report showed that air pollution does not affect everyone in the same way; certain vulnerable populations (e.g., children, the elderly, and cardiopulmonary patients, etc.) are more susceptible than others [33]. The US EPA defined the 'risk population' as being those who possess a significantly higher probability of developing a condition, illness or other abnormal status, and divided them into five groups, namely: (1) children aged less than or equal to 13 years; (2) older people aged greater or equal to 65 years; (3) a young person with asthma, who is less or equal than the age of 18 years; (4) legal adults with asthma; (5) people with COPD [34]. Children and older people are more sensitive than others with regards to indoor air pollution [35-39]. While the immune and metabolic systems of children are still developing, and their organs are immature, they are exposed to air pollutants due to which they suffer from frequent respiratory infections [40,41]. Older people are affected by IAQ due to weaker immune systems, undiagnosed respiratory conditions, and cardiovascular health conditions. A hazardous substance can aggravate heart diseases, strokes, and lung diseases such as chronic bronchitis and asthma [42,43].

Asthma is a chronic disease that often causes an exacerbation of disease activity, some of which result in hospitalizations. Air quality measures—such as $\mathrm{PM}_{2.5}, \mathrm{NO}_{2}, \mathrm{O}_{3}$, and dampness-related contaminants-play a significant role in asthma exacerbation, as well as disease progression. Asthmatic children spend $60 \%$ of their waking hours in school. A recent large-scale study [44] showed that co-exposure to elevated endotoxin levels and $\mathrm{PM}_{2.5}$ was synergistically correlated with increased emergency room visits, especially for asthma among children. Exposure to higher concentrations of endotoxin and $\mathrm{NO}_{2}$ was also synergistically associated with increased asthma attacks, despite below-normal geometric mean concentrations of $\mathrm{PM}_{2.5}, \mathrm{O}_{3}$ and $\mathrm{NO}_{2}$ compared to EPA NAAQ standards [44,45]. A 2015 update to the 2000 review of the Institute of Medicine [46] suggested that - in addition to endotoxin levels_-dampness, and dampness-related agents are also important environmental quality indicators for asthma. 
According to the ALA 'State of the Air ${ }^{\circledR} 2020$ ' report, $45.8 \%$ of people in the U.S. live in counties with unhealthy levels of air pollution; among these, 22 million people are elderly (equal or over age 65), and 34.2 million are children (less than age 18); 2.5 million of the children, and more than 10.6 million of the elderly people, have asthma; 7 million people have COPD; 77,000 people have lung cancer; 9.3 million have cardiovascular issues; and 18.7 million live in poverty [47].

Particularly with an increase in urbanization, the importance of IAQ cannot be understated. For this reason, we conducted a systematic review of air quality sensors, guidelines, and measurement studies for IAQ management. Section 2 discusses common air pollutants-such as $\mathrm{O}_{3}, \mathrm{CO}, \mathrm{CO}_{2}, \mathrm{SO}_{2}$, $\mathrm{NO}_{2}, \mathrm{PM}$, and TVOCs-that affect IAQ. Section 3 provides a detailed review of the currently-used air quality sensors for $\mathrm{O}_{3}, \mathrm{CO}, \mathrm{CO}_{2}, \mathrm{SO}_{2}, \mathrm{NO}_{2}, \mathrm{PM}$, and TVOCs, their measurement tolerances, and their measuring ranges. Section 4 discusses air quality-related guidelines, such as U.S. EPA NAAQS, OSHA, WHO, ACGIH, ANSI/ASHRAE, CAAQS, and NIOSH. In addition to the discussions related to common air pollutants and air quality guidelines, we provide a thorough list of the air quality studies conducted between 2015 and 2019 in Section 5. This is followed by discussions and recommendations in Section 6, and the conclusion in Section 7.

\section{Common Air Pollutants that Affect IAQ}

The most common air pollutants that affect IAQ are $\mathrm{O}_{3}, \mathrm{CO}, \mathrm{CO}_{2}, \mathrm{SO}_{2}, \mathrm{NO}_{2}, \mathrm{PM}$, and VOCs. Here, we discuss the pathophysiologic mechanisms of each of these air pollutants:

$\mathrm{O}_{3}$, as a pollutant, is the result of a chemical reaction between $\mathrm{NO}_{2}$ and VOCs in exposure to sunlight. It can be worse in both hot and cold environments [48]. The sources are from the emission of chemical solvents, electric utilities, and gasoline vapors. It can lead to lung inflammation and airway narrowing [49]. People with underlying diseases, children, and the elderly are the highest risk populations for $\mathrm{O}_{3}$ pollutants [50].

$\mathrm{CO}$ is a toxic gas that is odorless, colorless, and tasteless. Various sources of this gas are from unvented fuel and gas type space heaters, leaky chimneys and furnaces, tobacco smoke, furnace backdraft, gas-type water heaters, wood stoves and fireplaces, gas-powered equipment, and worn or poorly-adjusted and maintained combustion devices. It can cause fatigue, chest pain, angina, reduced brain function, impaired vision and coordination, dizziness, nausea, flu-like symptoms, and fetal death [51].

$\mathrm{CO}_{2}$ is defined by both the EPA and IPCC as an anthropogenic air pollutant, which is colorless and odorless. The primary source of indoor $\mathrm{CO}_{2}$ pollutants is the occupant's respiration. The US EPA BASE shows that high $\mathrm{CO}_{2}$ concentrations are associated with an increased prevalence of many SBS symptoms [52,53].

$\mathrm{SO}_{2}$ is the major precursor to the ambient $\mathrm{PM}_{2.5}$ level [54]. The combustion of coal, oil, and gas that contains sulfur are the leading sources of the indoor $\mathrm{SO}_{2}$ concentration [55]. Mostly, outdoor $\mathrm{SO}_{2}$ concentrations are $20 \%$ to $70 \%$ higher than indoors [56]. Short-term exposure to $\mathrm{SO}_{2}$ can cause respiratory illnesses, airway inflammation, and varying degrees of toxic symptoms [57-59]. Asthmatics, children, and older adults are potentially susceptible to this pollutant [54,55].

$\mathrm{NO}_{2}$ is a highly reactive gas which is related to the development of ozone and $\mathrm{PM}_{2.5} \cdot \mathrm{NO}_{2}$ primarily gets into the air from the burning of fuel. Similarly to sulfur dioxide, it can cause respiratory symptoms and airway inflammation. Asthmatics, children, and older adults are at higher risk from this pollutant [60].

PM is a mixture of solid and liquid particles embodied in the air, including acids, organic chemicals, soot, metals, soil, and dust. Particle pollution can be categorized by its size (diameter), which includes $\mathrm{PM}_{10}\left(2.5 \mu \mathrm{m}\right.$ to $10 \mu \mathrm{m}$ ), $\mathrm{PM}_{2.5}$ (less than $2.5 \mu \mathrm{m}$ ) and $\mathrm{PM}_{1.0}$ (less than $1.0 \mu \mathrm{m}$ ) [61]. $\mathrm{PM}_{10}$ affects the nasal and oral cavities, the pharynx, the larynx, and the upper trachea. $\mathrm{PM}_{2.5}$ are fine inhalable particles that form sediments on the surface of epithelial cells in the bronchioles and alveoli. $\mathrm{PM}_{1.0}$ can lead inward to internal organs, including the heart and brain [62,63]. " $\mathrm{PM}_{2.5}$ and $\mathrm{PM}_{1.0}$ can lead to pulmonary infection and generate vascular and endothelial dysfunction, alterations in heart rate 
variability, coagulation, and cardiac autonomic function" [64]. PM is estimated to cause of 3.3 million deaths per year worldwide [65]. Children, the elderly, and people with heart and lung disease are the high-risk populations for PM pollutants [50].

VOCs represent a diverse set of hazardous organic chemicals that participate in atmospheric photochemical reactions, which are considered to be one of the major contributors to SBS $[6,66,67]$. The WHO classifies both indoor and outdoor VOCs as Very-VOCs (VVOCs), VOCs, and Semi-VOCs (SVOCs) according to their boiling points [68]. Many studies have shown that the concentrations of many indoor VOCs were markedly higher than their outdoor counterparts [69-71]. The main indoor VOC sources include high-emission building materials, furnishings, aerosol sprays, pesticides, dry knitted products, office equipment such as copiers, and laser printers $[6,67,70,72]$. The US EPA issued a list of hazardous air pollutants, which include a total of 187 VOCs [73]. In addition, the ANSI/ASHRAE 62.1-2016 standard provides the Reference Exposure Levels (RELs) of 32 specific types of indoor VOCs for the general population [74]. The most common indoor VOCs-such as benzene, ethylene, formaldehyde, methylene chloride, tetrachloroethylene, toluene, xylene, and 1,3-butadiene-have been proven to be contributors of human carcinogens, irritants and toxicants [75-77]. TVOCs are used as a measure of the total volume of indoor VOC concentrations [78,79]. "Acute exposure to indoor TVOCs can cause eye, nose and throat irritation, headaches, loss of coordination and nausea, damage to the liver, kidney and central nervous system, respiratory disease and some cause cancer" [67]. Asthmatics, young children, and elderly people are more vulnerable to the effects of exposure to TVOCs $[6,77,79,80]$.

In addition to common air pollutants, the indoor temperature and relative humidity significantly affect IAQ. Fang et al. (1998) found out the overt linear correlation between the acceptability and enthalpy of IAQ. The results also identified that, under a constant pollution level, IAQ would decline with the increase of temperature and relative humidity [81]. Berglund and Cain (1989) concluded that the temperature's effect on IAQ was linear and stronger than humidity; the effect of the relative humidity on the acceptability of IAQ was higher in the dew point range of $11-20{ }^{\circ} \mathrm{C}$ than in the range of $2-11^{\circ} \mathrm{C}$, and relative humidity under $50 \%$ was acceptable to the IAQ performance [82].

\section{Air Quality Sensors, Measurement Tolerances, and Ranges}

In recent years, LCAQS technology has emerged from several laboratories for practical application, as they can be used to support real-time, spatial, and temporal data resolution for the monitoring of air concentration levels [83-85]. Additionally, more and more companies provide their own LCAQS products. The principles of operation for the low-cost gas-phase sensors are typically based on five major components, which are OPC, MOS, EC, NDIR, and PID [86,87]. Studies have shown that modern LCAQS provide useful qualitative information for scientific research, as well as for end-users $[85,88,89]$. However, due to the embedded technical uncertainties and lack of cross-validation and verification, there are certain limitations when comparing them to the expensive conventional equipment [87,90-92]. The US EPA has colloquially identified such devices to be low cost when their costs are less than US $\$ 2500$, because this is often the limit when they are considered for capital investment by scientists and end-users [83]. The price includes the sensor module, its networks, the interactive platform, and other supply services. Therefore, hereafter, we assert that LCAQs should be less than US $\$ 500$. Table 1 summarizes a series of commercially available LCAQs for primary air pollutants, such as $\mathrm{O}_{3}, \mathrm{CO}, \mathrm{CO}_{2}$, $\mathrm{SO}_{2}, \mathrm{NO}_{2}, \mathrm{PM}$, TVOCs. Furthermore, the specifications from the datasheet provided by the sensor companies-such as the repeatability, measuring range, circuit voltage, and response times-have been listed. The price of these LCAQS ranges between US $\$ 1$ and $\$ 500$, and they are capable of detecting an acceptable range of concentrations of each pollutant identified by the existing guidelines (See Table 2). 
Table 1. Commercially available LCAQs for the primary air pollutants.

\begin{tabular}{|c|c|c|c|c|c|c|c|}
\hline $\begin{array}{l}\text { Measured } \\
\text { Parameter }\end{array}$ & Example Product & Manufacturer & $\begin{array}{c}\text { Measurement Tolerance/ } \\
\text { Repeatability }\end{array}$ & Measuring Range & Circuit Voltage & Response Time & $\begin{array}{l}\text { Approx. Price } \\
\text { (USD). } 2019\end{array}$ \\
\hline \multirow{7}{*}{$\mathrm{O}_{3}$} & SR-G04 [93] & $\begin{array}{l}\text { BW Technologies/ } \\
\text { Honeywell }\end{array}$ & $\pm 5 \%$ & $0 \sim 1 \mathrm{ppm}$ & Not Provided & Not Provided & $\approx \$ 500$ \\
\hline & uHoo- $\mathrm{O}_{3}[94]$ & uHoo & $\pm 10 \mathrm{ppb}$ or $5 \%$ of reading & $0 \sim 1000 \mathrm{ppb}$ & $5.0 \mathrm{~V}$ & Not Provided & $\$ 300-500$ \\
\hline & DGS-O ${ }_{3} 968-042$ [96] & SPEC & $\pm 15 \%$ & $0 \sim 5 \mathrm{ppm}$ & $3.3 \mathrm{v}$ & $<30 \mathrm{~s}$ & $\$ 50-100$ \\
\hline & ULPSM-O $33968-005$ [97] & SPEC & $\pm 2 \%$ & $0 \sim 20 \mathrm{ppm}$ & $2.7 \mathrm{~V} \sim 3.3 \mathrm{~V}$ & $<30 \mathrm{~s}$ & $\$ 1-50$ \\
\hline & $\mathrm{ZE} 25-\mathrm{O}_{3}[98]$ & Winsen & Not Provided & $0 \sim 10 \mathrm{ppm}$ & $3.7 \mathrm{~V} \sim 5.5 \mathrm{~V}$ & $\leq 90 \mathrm{~s}$ & $\$ 1-50$ \\
\hline & MQ131 [99] & Winsen & Not Provided & $10 \sim 1000 \mathrm{ppm}$ & $\leq 24 \mathrm{~V} \mathrm{DC}$ & Not Provided & $\$ 1-50$ \\
\hline & MiCS-2610 [100] & SGX SensorTech & Not Provided & $10 \sim 1000 \mathrm{ppb}$ & $5.0 \mathrm{v}$ & Not Provided & $\$ 1-50$ \\
\hline \multirow{11}{*}{$\mathrm{CO}$} & uHoo-CO [101] & uHoo & $\pm 10 \mathrm{ppm}$ & $0 \sim 1000 \mathrm{ppm}$ & $5.0 \mathrm{v}$ & Not Provided & $\$ 300-500$ \\
\hline & CO-B4 [102,103] & Alphasense & $\pm 1 \mathrm{ppm}$ & $0 \sim 1000 \mathrm{ppm}$ & Not Provided & $1 \mathrm{~s}$ & $\$ 100-300$ \\
\hline & MNS-9-W2-GS-C1 [104] & Monnit & $\pm 2 \%$ of reading or $1 \mathrm{ppm}$ & $0 \sim 1000 \mathrm{ppm}$ & $2.0 \sim 3.6 \mathrm{v}$ & $<40 \mathrm{~s}\left(\right.$ at $\left.20^{\circ} \mathrm{C}\right)$ & $\$ 100-300$ \\
\hline & DGS-CO 968-034 [105] & SPEC & $< \pm 3 \%$ of reading or $2 \mathrm{ppm}$ & 0 to $1000 \mathrm{ppm}$ & $3.3 \mathrm{v}$ & $<30 \mathrm{~s}$ & $\$ 50-100$ \\
\hline & MiCS-4514/CJMCU4541 [106] & SGX SensorTech & Not Provided & $1 \sim 1000 \mathrm{ppm}$ & $5.0 \mathrm{v}$ & Not Provided & $\$ 1-50$ \\
\hline & TGS 5342 [107] & FIGARO & $\pm 10 \mathrm{ppm}$ & $0 \sim 10,000 \mathrm{ppm}$ & $5.0 \mathrm{v}$ & $60 \mathrm{~s}$ & $\$ 1-50$ \\
\hline & TGS 2442 [108] & FIGARO & Not SProvided & $30 \sim 1000 \mathrm{ppm}$ & $5.0 \mathrm{v}$ & $1 \mathrm{~s}$ & $\$ 1-50$ \\
\hline & HS-134 [109] & Sencera & Not Provided & $20 \sim 1000 \mathrm{ppm}$ & $5.0 \mathrm{v}$ & $<2 \mathrm{~s}$ & $\$ 1-50$ \\
\hline & MiCS-5524 [110] & SGX SensorTech & Not Provided & $1 \sim 1000 \mathrm{ppm}$ & $5.0 \mathrm{v}$ & $<25 \mathrm{~s}$ & $\$ 1-50$ \\
\hline & TGS5042 [111] & FIGARO & $< \pm 10 \mathrm{ppm}$ & $0 \sim 10,000 \mathrm{ppm}$ & $5.0 \mathrm{v}$ & $5.0 \mathrm{v}$ & $\$ 1-50$ \\
\hline & MQ-7 [112] & HANWEI & Not Provided & $20 \sim 2000 \mathrm{ppm}$ & $5.0 \mathrm{v}$ & $\leq 150 \mathrm{~s}$ & $\$ 1-50$ \\
\hline \multirow{9}{*}{$\mathrm{CO}_{2}$} & GC0028/CM-40301 [113] & The SprintIR ${ }^{\circledR}-6 \mathrm{~S}$ & $\begin{array}{c} \pm 70 \mathrm{ppm} \\
\pm 5 \% \text { of reading }\end{array}$ & $0-5 \%$ & $3.25 \sim 5.5 \mathrm{v}$ & $\begin{array}{l}\text { Flow Rate } \\
\text { Dependent }\end{array}$ & $\$ 100-300$ \\
\hline & AW6404 [114] & AWAIR & $\begin{array}{c} \pm 75 \mathrm{ppm} \\
(400 \text { to } 6000 \mathrm{ppm})\end{array}$ & $0 \sim 4000 \mathrm{ppm}$ & $5.0 \mathrm{v}$ & $3 \mathrm{~min}$ & $\$ 100-300$ \\
\hline & B-530 [115] & ELT SENSOR & $\begin{array}{l} \pm 30 \text { ppm } \\
\pm 3 \% \text { reading }\end{array}$ & $0 \sim 50,000 \mathrm{ppm}$ & $9 \sim 15 \mathrm{v}$ & $120 \mathrm{~s}$ & $\$ 100-300$ \\
\hline & FBT0002100 [116] & Foobot (Airboxlab) & $\begin{array}{c} \pm 1.0 \mathrm{ppm} \\
(400 \text { to } 6000 \mathrm{ppm})\end{array}$ & $400 \sim 6000 \mathrm{ppm}$ & Not Provided & Not Provided & $\$ 100-300$ \\
\hline & 8096-AP [117] & Air Mentor Pro & $\pm 5 \%$ & 400 2000 ppm & $\begin{array}{l}3.7 \mathrm{v} \\
475 \sim 525\end{array}$ & Not Provided & $\$ 100-300$ \\
\hline & $\begin{array}{l}\text { Yocto- } \mathrm{CO}_{2}[118] \\
\text { NWS01-EU [119] }\end{array}$ & $\begin{array}{l}\text { Yoctopuce } \\
\text { Netatmo }\end{array}$ & $\begin{array}{c} \pm 30 \mathrm{ppm} \pm 55 \% \\
\pm 5 \% \\
\text { (1000 to } 5000 \mathrm{ppm})\end{array}$ & $\begin{array}{l}0-10,000 \mathrm{ppm} \\
0 \sim 5000 \mathrm{ppm}\end{array}$ & $\begin{array}{c}4.75 \sim 5.25 \\
5.0 \mathrm{v}\end{array}$ & $\begin{array}{l}2 \mathrm{~s} @ 0.5 \mathrm{~L} / \mathrm{min} \\
\text { Not Provided }\end{array}$ & $\$ 100-300$ \\
\hline & CozIR $^{\circledR}$-LP2 [120] & GSS & $\pm 30 \mathrm{ppm} \pm 3 \%$ reading & $0-5000 \mathrm{ppm}$ & $3.25-5.5 \mathrm{v}$ & $30 \mathrm{~s}$ & $\$ 100-300$ \\
\hline & K-30 [121] & CO2Meter & $\begin{array}{c} \pm 30 \mathrm{ppm} / \\
\pm 3 \% \text { of reading }\end{array}$ & $0 \sim 5000 \mathrm{ppm}$ & $4.5-14 \mathrm{v}$ & $2 \mathrm{~s} @ 0.5 \mathrm{~L} / \mathrm{min}$ & $\$ 50-100$ \\
\hline & D-400 [122] & ELT SENSOR & $\begin{array}{c} \pm 30 \text { ppm } \\
\pm 3 \% \text { of Reading }\end{array}$ & $0 \sim 2000 \mathrm{ppm}$ & $4.75 \sim 12 \mathrm{v}$ & $30 \mathrm{~s}$ & $\$ 100-300$ \\
\hline
\end{tabular}


Table 1. Cont

\begin{tabular}{|c|c|c|c|c|c|c|c|}
\hline $\begin{array}{l}\text { Measured } \\
\text { Parameter }\end{array}$ & Example Product & Manufacturer & $\begin{array}{c}\text { Measurement Tolerance/ } \\
\text { Repeatability }\end{array}$ & Measuring Range & Circuit Voltage & Response Time & $\begin{array}{l}\text { Approx. Price } \\
\text { (USD). } 2019\end{array}$ \\
\hline \multirow{10}{*}{$\mathrm{CO}_{2}$} & GC-0015 [123] & $\operatorname{MinIR}^{\mathrm{TM}}$ & $\begin{array}{c} \pm 70 \text { ppm } \\
\pm 5 \% \text { of reading }\end{array}$ & $0-5 \%$ & $3.3 \pm 0.1 \mathrm{v}$ & $4 \sim 2 \mathrm{~min}$ & $\$ 100-300$ \\
\hline & ELT T110 [124] & ELT SENSOR & $\begin{array}{c} \pm 50 \text { ppm } \\
\pm 3 \% \text { reading }\end{array}$ & $400 \sim 2000$ ppm & $3.2 \mathrm{v} \sim 3.55 \mathrm{v}$ & $90 \mathrm{~s}$ & $\$ 50-100$ \\
\hline & MT-100 [125] & ELT SENSOR & $\begin{array}{c} \pm 70 \text { ppm } \\
\pm 3 \% \text { of reading }\end{array}$ & $0 \sim 10,000$ ppm & $3.5 \sim 5.2 \mathrm{~V}$ & $120 \mathrm{~s}$ & $\$ 50-100$ \\
\hline & S-300 [126] & ELT SENSOR & $\begin{array}{l} \pm 30 \text { ppm } \\
\pm 3 \% \text { measure }\end{array}$ & $0 \sim 2000 \mathrm{ppm}$ & $5.0 \mathrm{~V} \pm 5 \%$ & $60 \mathrm{~s}$ & $\$ 50-100$ \\
\hline & T6713 [127] & Telaire & $\pm 3 \%$ & $0 \sim 5000 \mathrm{ppm}$ & $4.5-5.5 \mathrm{v}$ & $3 \mathrm{~min}$ & $\$ 50-100$ \\
\hline & T6615 [128] & Telaire & $\pm 10 \%$ of reading & $0 \sim 50,000 \mathrm{ppm}$ & $5 \mathrm{v}$ & $2 \min$ & $\$ 50-100$ \\
\hline & MG811 [129] & Winsen & $\pm 75 \mathrm{ppm}$ & $350 \sim 10,000$ ppm & $7.5-12 \mathrm{v}$ & Not Provided & $\$ 1-50$ \\
\hline & TGS4161 [130] & FIGARO & $\pm 20 \%$ at $1000 \mathrm{pm}$ & $350 \sim 10,000 \mathrm{ppm}$ & $5.0 \pm 0.2 \mathrm{v}$ & $1.5 \mathrm{~min}$ & $\$ 1-50$ \\
\hline & MH-Z16 NDIR CO 2 [131] & Winsen & $\begin{array}{c} \pm 50 \mathrm{ppm} \\
\pm 5 \% \text { of reading }\end{array}$ & $0 \sim 5000 \mathrm{ppm}$ & $3.3 \mathrm{v}$ & $30 \mathrm{~s}$ & $\$ 1-50$ \\
\hline & MH-Z19 [132] & Winsen & $\begin{array}{l} \pm 50 \mathrm{ppm} \\
\pm 5 \% \text { reading }\end{array}$ & $0 \sim 5000 \mathrm{ppm}$ & $3.3 \mathrm{v}$ & $60 \mathrm{~s}$ & $\$ 1-50$ \\
\hline \multirow{6}{*}{$\mathrm{SO}_{2}$} & $\mathrm{~B} 4 \mathrm{SO}_{2}[133]$ & Alphasense & $\pm 5 \mathrm{ppb}$ & $0 \sim 100 \mathrm{ppm}$ & $3 v$ & $30 \mathrm{~s}$ & $\$ 100-300$ \\
\hline & ME4-SO ${ }_{2}[134]$ & Winsen & $\pm 2 \%$ & 200 ppm & Not Provided & $30 \mathrm{~s}$ & $\$ 100-300$ \\
\hline & DGS-SO 2 968-038 [135] & SPEC & $\pm 15 \%$ & $0 \sim 20 \mathrm{ppm}$ & $3.0 \mathrm{v}$ & $30 \mathrm{~s}$ & $\$ 50-100$ \\
\hline & $\mathrm{EC}-4 \mathrm{SO}_{2}-2000[136]$ & $\begin{array}{l}\text { Qingdao Scienoc } \\
\text { Chemical }\end{array}$ & $\pm 2 \%$ & $0 \sim 2000 \mathrm{ppm}$ & Not Provided & $60 \mathrm{~s}$ & $\$ 50-100$ \\
\hline & MQ-136 [137] & HANWEI & $\pm 2 \%$ & $1-100 \mathrm{ppm}$ & $5 \mathrm{v} \pm 0.1$ & $60 \mathrm{~s}$ & $\$ 1-50$ \\
\hline & FECS43-20 [138] & FIGARO & $\pm 2 \%$ & $0 \sim 20 \mathrm{ppm}$ & Not Provided & $25 \mathrm{~s}$ & Not Provided \\
\hline \multirow{6}{*}{$\mathrm{NO}_{2}$} & uHoo- $\mathrm{NO}_{2}$ [101] & uHoo & $\begin{array}{c} \pm 10 \mathrm{ppb} \\
\pm 5 \% \text { of reading }\end{array}$ & $0 \sim 1000 \mathrm{ppb}$ & $5.0 \mathrm{v}$ & Not Provided & $\$ 300-500$ \\
\hline & DGS-NO 2 968-043 [139] & SPEC Sensors & $\pm 15 \%$ & $0 \sim 10 \mathrm{ppm}$ & $3 v$ & $30 \mathrm{~s}$ & $\$ 50-100$ \\
\hline & Mics-6814 [140] & SGX SensorTech & $\pm 10 \mathrm{ppb}$ & $0.05-10 \mathrm{ppm}$ & $5.0 \mathrm{v}$ & $30 \mathrm{~s}$ & $\$ 1-50$ \\
\hline & MiCS-4514/CJMCU4541 [106] & SGX SensorTech & Not Provided & $1 \sim 1000 \mathrm{ppm}$ & $5.0 \mathrm{v}$ & Not Provided & $\$ 1-50$ \\
\hline & MiCS-2714 [141] & SGX SensorTech & Not Provided & $0.05 \sim 10 \mathrm{ppm}$ & $4.9 \sim 5.1 \mathrm{v}$ & $30 \mathrm{~s}$ & $\$ 1-50$ \\
\hline & $\mathrm{B} 4 \mathrm{NO}_{2}[142]$ & Alphasense & $\pm 12 \mathrm{ppb}$ & $0 \sim 50 \mathrm{ppm}$ & $3.5 \sim 6.4 \mathrm{v}$ & $25 \mathrm{~s}$ & $\$ 1-50$ \\
\hline
\end{tabular}


Table 1. Cont.

\begin{tabular}{|c|c|c|c|c|c|c|c|}
\hline $\begin{array}{l}\text { Measured } \\
\text { Parameter }\end{array}$ & Example Product & Manufacturer & $\begin{array}{c}\text { Measurement Tolerance/ } \\
\text { Repeatability }\end{array}$ & Measuring Range & Circuit Voltage & Response Time & $\begin{array}{l}\text { Approx. Price } \\
\text { (USD). } 2019\end{array}$ \\
\hline \multirow{12}{*}{$\mathrm{PM}$} & uHoo-PM ${ }_{2.5}[101]$ & uHoo & $\pm 20 \mu \mathrm{g} / \mathrm{m}^{3}$ & $0 \sim 200 \mu \mathrm{g} / \mathrm{m}^{3}$ & $5.0 \mathrm{v}$ & Not Provided & $\$ 300-500$ \\
\hline & DC1100 Pro [143] & Dylos & Not Provided & $0 \sim 1000 \mu \mathrm{g} / \mathrm{m}^{3}$ & $9 \mathrm{v}$ & Not Provided & $\$ 100-300$ \\
\hline & OPC-N2 [144] & Alphasense & Not Provided & $0.38 \sim 17 \mu \mathrm{m}$ & $4.8 \sim 5.2 \mathrm{v}$ & Not Provided & $\$ 100-300$ \\
\hline & AW6404 [146] & AWAIR & $\begin{array}{c} \pm 15 \mu \mathrm{g} / \mathrm{m}^{3} \\
15 \% \text { of reading }\end{array}$ & $0 \sim 1000 \mu \mathrm{g} / \mathrm{m}^{3}$ & $5 \mathrm{~V} / 2.0 \mathrm{~A}$ & Not Provided & $\$ 100-300$ \\
\hline & $\begin{array}{l}\text { 8096-AP [147] } \\
\text { SPS30 [148] }\end{array}$ & $\begin{array}{l}\text { Air Mentor Pro } \\
\text { Sensirion }\end{array}$ & $\begin{array}{c}\text { Not Provided } \\
\pm 10 \mu \mathrm{g} / \mathrm{m}^{3}\end{array}$ & $\begin{array}{c}0 \sim 300 \mu \mathrm{\mu g} / \mathrm{m}^{3} \\
0 \sim 1000 \mu \mathrm{\mu g} / \mathrm{m}^{3}\end{array}$ & $\begin{array}{c}3.7 \mathrm{v} \\
4.5 \sim 5.5 \mathrm{v}\end{array}$ & $\begin{array}{l}\text { Not Provided } \\
\quad 60 \mathrm{~s}\end{array}$ & $\begin{array}{c}\$ 100-300 \\
\$ 1-50\end{array}$ \\
\hline & PMS7003 [149] & Plantower & $\begin{array}{c} \pm 10 @ \\
100 \sim 500 \mu \mathrm{\mu g} / \mathrm{m}^{3}\end{array}$ & $0 \sim 500 \mu \mathrm{g} / \mathrm{m}^{3}$ & $5.0 \sim 5.5 \mathrm{v}$ & $10 \mathrm{~s}$ & $\$ 1-50$ \\
\hline & PMS5003 [150] & Plantower & $\begin{array}{c} \pm 10 @ \\
100 \sim 500 \mathrm{ug} / \mathrm{m}^{3}\end{array}$ & $0 \sim 500 \mu \mathrm{g} / \mathrm{m}^{3}$ & $5.0 \sim 5.5 \mathrm{v}$ & $10 \mathrm{~s}$ & $\$ 1-50$ \\
\hline & HPMA115S0-XXX [151] & Honeywell & $\pm 15 \mu \mathrm{g} / \mathrm{m}^{3}$ & $0 \sim 1000 \mu \mathrm{gg} / \mathrm{m}^{3}$ & $5 \pm 0.2 \mathrm{v}$ & $6 \mathrm{~s}$ & $\$ 1-50$ \\
\hline & DN7C3CA006 [152] & $\begin{array}{c}\text { Sharp } \\
\text { Microelectronics }\end{array}$ & \pm 0.2 & $25 \sim 500 \mu \mathrm{g} / \mathrm{m} 3$ & $5 \pm 0.1 \mathrm{v}$ & Not Provided & $\$ 1-50$ \\
\hline & SDS011 [153] & Nova Fitness & $\begin{array}{c}15 \% \\
\pm 10 \mu \mathrm{g} / \mathrm{m}^{3}\end{array}$ & $0.0-999.9 \mu \mathrm{g} / \mathrm{m}^{3}$ & $5 \mathrm{~V}$ & Not Provided & $\$ 1-50$ \\
\hline & Shinyei PPD42NS [154] & Shinyei & Not Provided & $0 \sim 28,000 \mathrm{pcs} /$ liter & $5.0 \sim 5.5 \mathrm{v}$ & $60 \mathrm{~s}$ & $\$ 1-50$ \\
\hline & TIDA-00378 [155] & TI Designs & $\begin{array}{c}75 \% \text { Over } \\
\text { Detection Range }\end{array}$ & $12 \sim 35 \mathrm{pcs} / \mathrm{cm}^{3}$ & $3.3 \mathrm{~V}$ & Not Provided & Not Provided \\
\hline \multirow{11}{*}{$\mathrm{t}$-VOCs } & 8096-AP [117] & Air Mentor Pro & Not Provided & $0 \sim 300 \mu \mathrm{g} / \mathrm{m}^{3}$ & $3.7 \mathrm{v}$ & Not Provided & $\$ 100-300$ \\
\hline & AW6404 [146] & AWAIR & $\pm 10 \%$ & $0 \sim 60,000 \mathrm{ppb}$ & $5.0 \mathrm{v}$ & $60 \mathrm{~s}$ & $\$ 100-300$ \\
\hline & FBT0002100 [145] & Foobot (Airboxlab) & $\pm 10 \%$ & $0 \sim 1000 \mathrm{ppb}$ & Not Provided & Not Provided & $\$ 100-300$ \\
\hline & ZMOD4410 [156] & IDT & $\pm 10 \%$ & $0 \sim 1000 \mathrm{ppm}$ & $1.7 \sim 3.6 \mathrm{v}$ & $5 \mathrm{~s}$ & $\$ 50-100$ \\
\hline & Yocto-VOC-V3 [157] & Yoctopuce & Not Provided & $0 \sim 65,000 \mathrm{ppb}$ & Not Provided & Not Provided & $\$ 50-100$ \\
\hline & uThing::VOC' & Ohmetech.io & $+15 \%$ & $0-500$ & $5.0 \mathrm{v}$ & $3 \mathrm{~s}$ & $\$ 50-100$ \\
\hline & MiCS-5524 [159] & SGX SensorTech & Not Provided & $10 \sim 100 \mathrm{ppm}$ & Not Provided & Not Provided & $\$ 1-50$ \\
\hline & iAQ-100 C/110-802 [160] & SPEC & $\pm 2 \mathrm{ppm}$ & $0 \sim 100 \mathrm{ppm}$ & $12 \pm 2$ VDC & $20 \mathrm{~s}$ & $\$ 1-50$ \\
\hline & SP3_AQ2 [161] & Nissha FIS & Not Provided & $0 \sim 100 \mathrm{ppm}$ & $5 \mathrm{v} \pm 4 \%$ & Not Provided & $\$ 1-50$ \\
\hline & TGS2602 [162] & FIGARO & Not Provided & $1 \sim 30 \mathrm{ppm}$ & $5 \pm 0.2 \mathrm{v}$ & $30 \mathrm{~s}$ & $\$ 1-50$ \\
\hline & MICS-VZ-87 [163] & SGX SensorTech & Not Provided & $\begin{array}{l}\text { 400-2000 ppm } \\
\text { equivalent } \mathrm{CO}_{2}\end{array}$ & $5.0 \mathrm{v}$ & $30 \mathrm{~s}$ & $\$ 1-50$ \\
\hline
\end{tabular}


Table 2. Common air quality guidelines and standards.

\begin{tabular}{|c|c|c|c|c|c|c|c|}
\hline $\begin{array}{l}\text { Measured } \\
\text { Parameter }\end{array}$ & $\begin{array}{c}\text { NAAQS/EPA } \\
\text { (U.S. Enforceable) } \\
\text { [164-168] }\end{array}$ & $\begin{array}{c}\text { OSHA } \\
\text { (U.S. Enforceable) } \\
{[169]}\end{array}$ & $\begin{array}{c}\text { WHO/Europe } \\
\text { (Christopher et al., 2017; } \\
\text { WHO, 2016b, WHO, } \\
\text { 2010) }[170,171]\end{array}$ & ACGIH [172] & $\begin{array}{c}\text { ANSI/ } \\
\text { ASHRAE 62.1 } \\
\text { [173] }\end{array}$ & $\underset{\text { [173] }}{\text { NIOSH }}$ & $\begin{array}{c}\text { CAAQS } \\
\text { (SCAQMD) } \\
\text { [174] }\end{array}$ \\
\hline $\mathrm{O}_{3}$ & $\begin{array}{l}0.07 \mathrm{ppm} \\
(8-\mathrm{h} \text { mean }) \\
0.12 \mathrm{ppm} \\
(1 \mathrm{~h} \text { mean }) \\
0.08 \mathrm{ppm}\end{array}$ & $0.1 \mathrm{ppm}$ & $\begin{array}{l}120 \mu \mathrm{g} / \mathrm{m}^{3} \\
(8-\mathrm{h} \text { mean })\end{array}$ & $\begin{array}{c}0.3 \mathrm{ppm} \\
(15 \mathrm{~min}) \\
0.05 \mathrm{ppm} \\
\text { (heavy work) } \\
0.08 \mathrm{ppm} \\
\text { (moderate work) } \\
0.1 \mathrm{ppm} \\
\text { (light work) } \\
0.2 \mathrm{ppm} \\
\text { (work } \leq 2 \mathrm{~h} \text { ) }\end{array}$ & $\begin{array}{c}100 \mu \mathrm{g} / \mathrm{m}^{3} ; 50 \mathrm{ppb} \\
\quad(8-\mathrm{h} \text { mean })\end{array}$ & $\begin{array}{c}0.1 \mathrm{ppm} \\
\left(0.2 \mathrm{mg} / \mathrm{m}^{3}\right)\end{array}$ & $\begin{array}{l}0.07 \mathrm{ppm} \\
(8-\mathrm{h}) \\
0.09 \mathrm{ppm} \\
(1-\mathrm{h})\end{array}$ \\
\hline $\mathrm{CO}$ & $\begin{array}{c}9 \text { ppm } \\
(8-\mathrm{h} \text { mean }) \\
35 \mathrm{ppm} \\
(1 \mathrm{~h} \text { mean })\end{array}$ & $50 \mathrm{ppm}$ & $\begin{array}{c}100 \mathrm{mg} / \mathrm{m}^{3} \\
(15-\mathrm{min} \text { mean }) \\
35 \mathrm{mg} / \mathrm{m}^{3} \\
(1-\mathrm{h} \text { mean }) \\
10 \mathrm{mg} / \mathrm{m}^{3} \\
(8-\mathrm{h} \mathrm{mean}) \\
7 \mathrm{mg} / \mathrm{m}^{3} \\
(24-\mathrm{h} \text { mean }) \\
\end{array}$ & $\begin{array}{c}25 \mathrm{ppm} \\
(8-\mathrm{h})\end{array}$ & $\begin{array}{c}9 \text { ppm } \\
\text { (8-h mean) }\end{array}$ & $\begin{array}{c}35 \mathrm{ppm} \\
40 \mathrm{mg} / \mathrm{m}^{3} \\
(8-\mathrm{h} \mathrm{mean}) \\
200 \mathrm{ppm} \\
\left(229 \mathrm{mg} / \mathrm{m}^{3}\right) \\
\text { ceiling }\end{array}$ & $\begin{array}{c}20 \mathrm{ppm}, \\
(1-\mathrm{H} \text { mean }) \\
9.0 \mathrm{ppm}, \\
(8-\mathrm{H} \text { mean })\end{array}$ \\
\hline $\mathrm{CO}_{2}$ & N/A & $5000 \mathrm{ppm}$ & N/A & $\begin{array}{c}5000 \mathrm{ppm} \\
(8-\mathrm{h}) \\
30,000 \mathrm{ppm} \\
(15 \text { min mean })\end{array}$ & $\begin{array}{c}5000 \mathrm{ppm} \\
300 \sim 500 \mathrm{ppm} \\
\text { (outdoor suggest) } \\
1000 \mathrm{ppm} \\
\text { (indoor suggest) }\end{array}$ & $\begin{array}{c}5000 \mathrm{ppm} \\
\left(9000 \mathrm{mg} / \mathrm{m}^{3}\right) \\
30,000 \mathrm{ppm} \\
(15 \mathrm{~min}) \\
\left(54,000 \mathrm{mg} / \mathrm{m}^{3}\right)\end{array}$ & N/A \\
\hline $\mathrm{SO}_{2}$ & $\begin{array}{c}75 \mathrm{ppb} \\
\text { (1-h mean) }\end{array}$ & $5 \mathrm{ppm}$ & $\begin{array}{c}20 \mu \mathrm{g} / \mathrm{m}^{3} \\
(24-\mathrm{h} \mathrm{mean}) \\
500 \mu \mathrm{g} / \mathrm{m}^{3} \\
(10-\mathrm{min} \text { mean })\end{array}$ & $\begin{array}{c}0.25 \mathrm{ppm} \\
(15 \mathrm{~min})\end{array}$ & $\begin{array}{c}80 \mu \mathrm{g} / \mathrm{m}^{3} \\
\text { (Annual mean) }\end{array}$ & $\begin{array}{c}2 \mathrm{ppm} \\
\left(5 \mathrm{mg} / \mathrm{m}^{3}\right) \\
5 \mathrm{ppm} \\
\left(10 \mathrm{mg} / \mathrm{m}^{3}\right)\end{array}$ & $\begin{array}{c}0.25 \mathrm{ppm} \\
1-\mathrm{H} \text { mean } \\
0.04 \mathrm{ppm} \\
(24-\mathrm{h} \text { mean }) \\
\end{array}$ \\
\hline $\mathrm{NO}_{2}$ & $\begin{array}{c}100 \mathrm{ppb} \\
(1-\mathrm{h}) \\
53 \mathrm{ppb} \\
\text { (Annual mean) }\end{array}$ & $0.1 \mathrm{ppm}$ & $\begin{array}{c}200 \mu \mathrm{g} / \mathrm{m}^{3} \\
(0.1 \mathrm{ppm}) \\
(1-\mathrm{h} \mathrm{mean}) \\
40 \mu \mathrm{g} / \mathrm{m}^{3} \\
(0.02 \mathrm{ppm}) \\
(1-y r \text { average) }\end{array}$ & $\begin{array}{c}0.02 \\
(15 \mathrm{~min})\end{array}$ & $\begin{array}{c}200 \mu \mathrm{g} / \mathrm{m}^{3} \\
(\text { Annual mean }) \\
470 \mu \mathrm{g} / \mathrm{m}^{3} \\
(24-\mathrm{h} \text { mean })\end{array}$ & $\begin{array}{c}1 \mathrm{ppm} \\
\left(1.8 \mathrm{mg} / \mathrm{m}^{3}\right)\end{array}$ & $\begin{array}{c}0.18 \mathrm{ppm}, \\
\text { (1-H mean) } \\
0.030 \mathrm{ppm}, \\
\text { (Annual mean) }\end{array}$ \\
\hline
\end{tabular}


Table 2. Cont.

\begin{tabular}{|c|c|c|c|c|c|c|c|}
\hline $\begin{array}{l}\text { Measured } \\
\text { Parameter }\end{array}$ & $\begin{array}{c}\text { NAAQS/EPA } \\
\text { (U.S. Enforceable) } \\
\text { [164-168] }\end{array}$ & $\begin{array}{c}\text { OSHA } \\
\text { (U.S. Enforceable) } \\
\text { [169] }\end{array}$ & $\begin{array}{c}\text { WHO/Europe } \\
\text { (Christopher et al., 2017; } \\
\text { WHO, 2016b, WHO, } \\
\text { 2010) }[170,171]\end{array}$ & ACGIH [172] & $\begin{array}{c}\text { ANSI/ } \\
\text { ASHRAE 62.1 } \\
\text { [173] }\end{array}$ & $\underset{[173]}{\text { NIOSH }}$ & $\begin{array}{c}\text { CAAQS } \\
\text { (SCAQMD) } \\
\text { [174] }\end{array}$ \\
\hline $\mathrm{PM}_{2.5}$ & $\begin{array}{c}35 \mu \mathrm{g} / \mathrm{m}^{3} \\
(24-\mathrm{h} \text { mean }) \\
12 \mu \mathrm{g} / \mathrm{m}^{3} \\
\text { (Annual mean) }\end{array}$ & $5 \mathrm{mg} / \mathrm{m}^{3}$ & $\begin{array}{c}25 \mu \mathrm{g} / \mathrm{m}^{3} \\
(24-\mathrm{h} \text { mean }) \\
10 \mu \mathrm{g} / \mathrm{m}^{3} \\
\text { (Annual mean) }\end{array}$ & $3 \mathrm{mg} / \mathrm{m}^{3}(8-\mathrm{h})$ & $15 \mu \mathrm{g} / \mathrm{m}^{3}$ & N/A & $\begin{array}{c}12 \mu \mathrm{g} / \mathrm{m}^{3} \\
\text { Annual mean }\end{array}$ \\
\hline $\mathrm{PM}_{10}$ & $\begin{array}{c}155 \mu \mathrm{g} / \mathrm{m}^{3} \\
(24-\mathrm{h} \text { mean) } \\
\text { (Not to be exceeded } \\
\text { more than once per year } \\
\text { on average over } 3 \text { years) }\end{array}$ & N/A & $\begin{array}{c}50 \mu \mathrm{g} / \mathrm{m}^{3} \\
(24-\mathrm{h} \text { mean }) \\
20 \mu \mathrm{g} / \mathrm{m}^{3} \\
\text { (Annual mean) }\end{array}$ & $10 \mathrm{mg} / \mathrm{m}^{3}(8-\mathrm{h})$ & $50 \mu \mathrm{g} / \mathrm{m}^{3}$ & N/A & $\begin{array}{c}50 \mu \mathrm{g} / \mathrm{m}^{3} \\
(24-\mathrm{H} \mathrm{mean}) \\
20 \mu \mathrm{g} / \mathrm{m}^{3} \\
\text { (Annual mean) }\end{array}$ \\
\hline $\mathrm{t}$-VOCs & $\begin{array}{c}200 \mu \mathrm{g} / \mathrm{m}^{3} \\
\text { AQI INDEX: } \\
0 \sim 50 \text { GOOD } \\
\text { 51 100 Moderate } \\
\text { 101 150 Unhealthy for } \\
\text { Sensitive Group } \\
\text { 151 200 Unhealthy } \\
\text { 201 300 Very Unhealthy } \\
\text { 301 500 Hazardous }\end{array}$ & N/A & $\begin{array}{l}300 \mu \mathrm{g} / \mathrm{m}^{3} \\
(8-\mathrm{h} \text { mean })\end{array}$ & N/A & $\begin{array}{c}\text { See full list on: } \\
\text { ASHRAE } \\
\text { Standard } 62.1 \\
\text { TVOC guidance }\end{array}$ & N/A & N/A \\
\hline
\end{tabular}




\section{Air Quality Guidelines}

Table 2 presents a series of common air quality guidelines and standards for industrial and non-industrial environments. The majority of these guidelines are being improved constantly by implementing different criteria and procedures. The ambient air quality standards set by NAAQS and CAAQs are used for outdoor environments, and those set by OSHA, NIOSH, and ACGIH are used for industrial environments. The guidelines set by ASHRAE are designed for indoor environments, especially where building HVAC systems are used, and the WHO air quality standards are designed for the general environment. The following are the descriptions of these individual guidelines, which can provide criteria information for the decision-maker in adopting these values.

The NAAQS (40 CFR part 50) are the criteria for the air pollutant standards enforced by the US EPA under the authority of the Clean Air Act (42 U.S.C.) [164,165]. The purpose of the primary standards of the NAAQS (2016) is to determine the acceptable range of seven principal pollutants ( $\mathrm{CO}, \mathrm{NO}_{2}$, Ozone, $\mathrm{PM}_{2.5}, \mathrm{PM}_{10}$, Lead, and $\mathrm{SO}_{2}$ ) for public health protection, including the high-risk populations [164,166]. In 2019, up to 1131 counties in the US published their ambient air quality data under the NAAQs in the national platform [167]. Multiple studies indicate that NAAQS are applicable to outdoor conditions, rather than indoors, due to the technical difficulties and specific properties of indoor pollutant concentrations $[166,167,170]$.

In 2006, the WHO published an air quality guideline, which was a global update edition based on the previous versions (WHO/Europe, 1987 and 2000) [164,165]. This guideline targeted five specific pollutants $\left(\mathrm{NO}_{2}\right.$, Ozone, $\mathrm{PM}_{2.5}, \mathrm{PM}_{10}$, and $\left.\mathrm{SO}_{2}\right)$ for application to the general environment $[167,173,175]$. In 2010, the WHO's regional office in Europe released the book 'The Guidelines for Indoor Air Quality: Selected Pollutants', according to a review of the overall WHO guidelines and the related indoor air quality studies [176]. The book provided threshold concentrations of selected indoor pollutants, such as $\mathrm{CO}, \mathrm{NO}_{2}$, benzene, formaldehyde, naphthalene, radon, and polycyclic aromatic hydrocarbons. However, a few of biases and limitations of the current $\mathrm{WHO}$ air quality guidelines were retained [177-179]. The meeting of the WHO Expert Consultation (2016) recommended a systematic re-evaluation of the health-related evidence, the interactions among pollutants, and the risk assessment of the biases, which are required to be performed for the new version of the WHO air pollutants guideline, which is expected to be published in 2020 (WHO, 2020) [178,180].

The ANSI/ASHRAE 62.1 and 62.2 standards of ventilation for acceptable indoor air quality are a non-judicial enforcement established by ASHRAE in 1973 [181]. The 2016 version of ANSI/ASHRAE 62.1 include contaminant concentration targets for ten types of indoor pollutants: $\mathrm{CO}, \mathrm{NO}_{2}, \mathrm{SO}_{2}, \mathrm{Ozone}$, $\mathrm{PM}_{2.5}, \mathrm{PM}_{10}$, Odors, Radon, Lead, and TVOCs [74,181-183]. The new version of the ANSI/ASHRAE 62.1-2019 standards puts more emphasis on the consideration of the interaction of the outdoor air quality with the HVAC system. Meanwhile, it prohibits any air-cleaning equipment that generates ozone $[178,180,184]$.

The NIOSH is the federal agency under the US CDC [173]. NIOSH and the US EPA have worked jointly on the guidance for the development, evaluation, and validation of the protocols for indoor air quality sampling since the early nineties [179]. NIOSH recommended a non-enforcement guideline for industrial environments, which includes Maximum Exposure Limits (MEL) for $\mathrm{CO}, \mathrm{NO}_{2}, \mathrm{SO}_{2}$, ozone, lead, and formaldehyde $[74,173,179]$. These are based on industry and workplace settings, and are not applicable to the high-risk populations [174].

The OSHA is a national public health agency which is separate from the U.S. DOL [180]. The OSHA developed enforceable guidelines for maximum exposure limits, which currently contain over 600 types of hazardous substances; some of these were adopted by the NIOSH and ACGIH [181,185,186]. The OSHA Permissible Exposure Limits (PELs), which were primarily designed for commercial and institutional buildings, have not been updated since $1970[169,180,181]$. Therefore, the OHSA and its related organizations recommend that employers and participants consider referencing the alternative guidelines for the uncovered scenarios, and OSHA PELs are not suggested to protect the high-risk populations $[74,169,173]$. 
The ACGIH TLVs ${ }^{\circledR}$ Committee has provided maximum permissible exposures for industrial workplaces since 1962 [172,187]. The current TLVs ${ }^{\circledR}$ guidelines (ACGIH, 2019) include more than 700 chemical substances [172]. The ACGIH's TLVs ${ }^{\circledR}$ developed time-weighted average concentration limits both for periods of $15 \mathrm{~min}$ (short-term) and for $8 \mathrm{~h}$ workdays (40-h a week) [187]. The ACGIH air quality guidelines are unenforced in the United States; they are intended to protect industrial workers, and should not be applied for sensitive or high-risk populations [181,187,188].

The CAAQS is part of the regional Air Quality Management Plans (AQMPs) developed by the CARB, and they have been updated jointly with the SCAQMD and the U.S. EPA [189]. According to the 2016 AQMP review (2016), the design value of seven principle pollutants (ozone, $\mathrm{CO}, \mathrm{NO}_{2}, \mathrm{SO}_{2}$, $\mathrm{PM}_{2.5}, \mathrm{PM}_{10}$, and lead) and additional three VOCs $\left(\mathrm{SO}_{4}{ }^{2-}, \mathrm{H}_{2} \mathrm{~S}\right.$, and $\left.\mathrm{C}_{2} \mathrm{H}_{3} \mathrm{Cl}\right)$ are set by CAAQS, which are enacted in a manner that is often more stringent than the NAAQS [190-192]. Under the authority of the Clean Air Act (CAA), the CAAQS were established to prevent adverse health and welfare effects for high-risk populations, but currently, the values are not enforceable [174,192-194].

\section{Air Quality Measurements and Data Analysis}

In recent years, the field measurement study of indoor and outdoor air quality has accelerated, and now includes numerous monitoring strategies. In Tables 3-5, we summarize studies that analyzed critical factors regarding the assessment of both indoor and outdoor air quality for occupant satisfaction. A total of 33 original papers, published from 2015 to 2019, are included for this narrative review; among these, 13 measurement studies were conducted in school buildings, six were focused on residential buildings, and 14 focused on other types of building (offices, hospitals, shopping malls, museums, metro stations, etc.). As the table presents, $\mathrm{PM}_{2.5}, \mathrm{PM}_{10}, \mathrm{CO}_{2}, \mathrm{VOCs}, \mathrm{CO}$, ozone, $\mathrm{NO}_{2}$, and $\mathrm{SO}_{2}$ are the commonly measured pollutants across the studies. Tables $3-5$ contains the list of the studies, in which most of them analyzed the correlation between indoor and outdoor concentrations, as well as the I/O ratio. They indicate that LQAS is rapidly being applied in practical applications and air quality research, but conventional and expensive quality monitors are still the mainstream equipment that is applied to IAQ research. Additionally, studies have been conducted using various equipment in different environments, and most choose their respective sampling protocols along with the approach of analyzing the output data. This shows that there is a lack of a uniform method for data quality and uncertainties control. Few of these studies considered the multicollinearity and cross-sensitivity between each of the sensors. The literature search was carried out based on the electronic databases Web of Science and Science Direct, using the keywords "Indoor air quality", "Indoor and outdoor concentrations", and "Field monitoring", and "Field measurement". 
Table 3. Air quality measurements and data analysis for school buildings.

\begin{tabular}{|c|c|c|c|c|c|c|c|}
\hline Study & Location & Subject & Indicators & Measuring Tool & Standard & Analysis/Program & Main Results \\
\hline $\begin{array}{c}\text { Ehsan et al., } 2019 \\
{[195]}\end{array}$ & $\begin{array}{c}\text { Mid-Atlantic } \\
\text { region, } \\
\text { the United States }\end{array}$ & $\begin{array}{l}16 \text { urban public } \\
\text { schools }\end{array}$ & $\begin{array}{l}\mathrm{CO} ; \mathrm{NO}_{2} ; \mathrm{CO}_{2} ; \\
\quad \mathrm{PM}_{2.5}\end{array}$ & $\begin{array}{c}\text { Sampler: } \\
\text { Personal DataRam, model } \\
\text { pDR-1200 monitor for PM; } \\
\text { AdvancedSense Pro } \\
\text { indoor air quality meter }\end{array}$ & WHO & $\begin{array}{l}\text { Wilcoxon } \\
\text { rank-sum, } \\
\text { Kruskal-Wallis } \\
\text { tests, Spearman } \\
\text { rank correlation } \\
\text { coefficient (I/O } \\
\text { correlation). } \\
\end{array}$ & $\begin{array}{l}\text { Outdoor Condition, school, } \\
\text { and room level found to } \\
\text { contribute significantly to } \\
\text { indoor pollutant } \\
\text { concentration. }\end{array}$ \\
\hline $\begin{array}{c}\text { Julie et al., } 2019 \\
\text { [196] }\end{array}$ & $\begin{array}{l}\text { Wellington, } \\
\text { New Zealand }\end{array}$ & primary school & $\begin{array}{c}\mathrm{NO}_{2}: \mathrm{CO}_{2} ; \mathrm{PM}_{2.5} ; \\
\mathrm{PM}_{10}\end{array}$ & $\begin{array}{l}\text { TSI Dusttrak II Aerosol } \\
\text { Monitors., Model 8530; } \\
\text { TSI Q-Trak IAQ monitor } \\
\text { Model 8552; } \\
\text { low-cost metal oxide type } \\
\text { sensor e2v MiCS-5525 (Air } \\
\text { Quality Egg); E-BAM } \\
\end{array}$ & $\begin{array}{l}\text { ISO 12103-1 AI } \\
\text { Test Dust; } \\
\text { ASHRAE }\end{array}$ & $\begin{array}{l}\text { Positive matrix } \\
\text { factorizat, ion }\end{array}$ & $\begin{array}{c}\mathrm{PM}_{2.5} \text { associated with } \\
\text { infiltration of TRAP; } \\
\mathrm{PM}_{10} \text { was significantly higher } \\
\text { than the outdoor level; } \\
\text { Natural ventilation as a key } \\
\text { role dropped IAQ of the } \\
\text { aquatic center. }\end{array}$ \\
\hline $\begin{array}{c}\text { Nkosi et al., } 2017 \\
\text { [197] }\end{array}$ & $\begin{array}{l}\text { Gauteng and } \\
\text { North West } \\
\text { provinces, } \\
\text { South Africa }\end{array}$ & Schools & $\mathrm{PM}_{10}$ and $\mathrm{SO}_{2}$ & $\begin{array}{l}\text { AEROQUAL mobile air } \\
\text { monitoring station }\end{array}$ & $\begin{array}{l}\text { South African Air } \\
\text { Quality Standard }\end{array}$ & $\begin{array}{l}\text { Univariate and } \\
\text { multiple backward } \\
\text { hierarchical } \\
\text { regression } \\
\text { analysis; } \\
\text { Spearman's } \\
\text { correlation } \\
\text { coefficients; }\end{array}$ & $\begin{array}{l}\text { A significant correlation } \\
\text { between } \mathrm{PM}_{10} \text { and indoor } \\
\text { dust; Indoor coal or fossil fuel } \\
\text { contributes to levels of } \mathrm{SO}_{2} ; \\
\text { pulmonary function and } \\
\text { respiratory symptom are very } \\
\text { sensitive to } \mathrm{SO}_{2}\end{array}$ \\
\hline $\begin{array}{c}\text { Raysoni et al., } 2017 \\
\text { [198] }\end{array}$ & $\begin{array}{c}\text { El Paso, } \\
\text { the United States }\end{array}$ & School Building & VOCs; & $\begin{array}{c}\text { Local central ambient } \\
\text { monitoring site (CAMS } \\
\text { 37); Passive badge } \\
\text { samplers } 3 \text { M } 3500 \\
\text { Organic Vapor Monitor }\end{array}$ & EPA; NAAQS & $\begin{array}{l}\text { Spearman's Rho } \\
\text { correlations }\end{array}$ & $\begin{array}{c}\text { All Indoor VOCs } \\
\text { concentrations are impacted } \\
\text { by traffic emissions; Toluene } \\
\text { concentrations were the } \\
\text { highest among the BTEX } \\
\text { group; }\end{array}$ \\
\hline $\begin{array}{l}\text { Kalimeri et al., } \\
2016 \text { [199] }\end{array}$ & Kozani, Greece & School Buildings & $\begin{array}{c}\mathrm{CO}_{2} ; \mathrm{CO} ; \mathrm{O}_{3} \mathrm{SO}_{2} ; \\
\text { VOCs; } \mathrm{PM}_{10} \\
\mathrm{PM}_{2.5} ; \mathrm{VOCs} ; \\
\text { Radon }\end{array}$ & $\begin{array}{l}\text { Radiello passive samplers; } \\
\text { Gammadata RAPIDOS } \\
\text { samplers; Telair 7001; } \\
\text { aeroQUAL CO sensors; } \\
\text { Derenda } \\
\text { LVS3.1/PMS3.1-15; Grimm } \\
\text { 1.108 }\end{array}$ & $\begin{array}{l}\text { ENV 13419, 2003, } \\
\text { ASTM 5116, 1997, } \\
\text { ISO 16000-3, 2001, } \\
\text { ISO 16000-6, 2004; } \\
\text { ASTM D6245-07; } \\
\text { SINPHONIE; EPA }\end{array}$ & $\begin{array}{l}\text { The Limit of } \\
\text { Detection }\end{array}$ & $\begin{array}{l}\text { The ventilation effect is the } \\
\text { major parameter affect IAQ. } \\
\text { Cleaning products, } \\
\text { do-it-yourself products might } \\
\text { increase indoor Formaldehyde } \\
\text { and benzene; Strong/positive } \\
\text { correlation between indoor } \\
\text { and outdoor } \mathrm{NO}_{2} \text { and } \mathrm{O}_{3} ; \\
\text { pupils' activities and outdoor } \\
\text { source effect } \mathrm{PM} \text { value; }\end{array}$ \\
\hline
\end{tabular}


Table 3. Cont

\begin{tabular}{|c|c|c|c|c|c|c|c|}
\hline Study & Location & Subject & Indicators & Measuring Tool & Standard & Analysis/Program & Main Results \\
\hline $\begin{array}{l}\text { Madureira et al., } \\
2016 \text { [200] }\end{array}$ & Portugal & $\begin{array}{l}\text { School Buildings } \\
\text { (73 primary } \\
\text { classrooms) }\end{array}$ & $\begin{array}{l}\text { VOCs, } \\
\text { aldehydes, } \mathrm{PM}_{2.5} \\
\mathrm{PM}_{10} \text {, bacteria and } \\
\text { fungi, } \mathrm{CO}_{2}, \mathrm{CO}\end{array}$ & $\begin{array}{c}\text { Thermally desorbed } \\
\text { adsorbents; } \\
\text { Dani STD 33.50; } \\
\text { gas chromatography; } \\
\text { Radiello }{ }^{\circledR} \text { passive devices; } \\
\text { TSI DustTrak DRX } \\
\text { photometers; single-stage } \\
\text { microbiological air } \\
\text { impactor }\end{array}$ & $\begin{array}{l}\text { WHO; } \\
\text { ISO 16000-1, } \\
\text { (2004). }\end{array}$ & $\begin{array}{l}\text { PCA; } \\
\text { Multilevel linear } \\
\text { regression; }\end{array}$ & $\begin{array}{c}\text { Ventilation, } \\
\text { Building } \\
\text { location, Occupant behavior, } \\
\text { maintenance/cleaning } \\
\text { activities associated with IAQ }\end{array}$ \\
\hline $\begin{array}{l}\text { Madureira et al., } \\
2016 \text { [201] }\end{array}$ & Porto, Portugal & $\begin{array}{l}\text { School Buildings } \\
20 \text { primary schools }\end{array}$ & $\mathrm{CO}_{2}, \mathrm{PM}_{10}, \mathrm{VOCs}$ & $\begin{array}{l}\text { Low-drift NDIR sensors; } \\
\text { light-scattering laser } \\
\text { photometers }\end{array}$ & $\begin{array}{c}\text { EPA } \\
\text { ASHRAE }\end{array}$ & $\begin{array}{l}\text { PCA; } \\
\text { Multilevel linear } \\
\text { regression; }\end{array}$ & $\begin{array}{c}\text { Activities or building } \\
\text { features as major sources of } \\
\text { indoor } \mathrm{CO}_{2}, \mathrm{PM}_{10} \text { and VOCs; } \\
\mathrm{PM}_{10} \text { levels increased by the } \\
\text { mixed source from indoor } \\
\text { activities }\end{array}$ \\
\hline $\begin{array}{c}\text { Oliveira et al., } 2016 \\
\text { [202] }\end{array}$ & Oporto, Portugal & $\begin{array}{l}\text { School Buildings } \\
\text { (Preschool) }\end{array}$ & $\begin{array}{c}\text { TVOCs; } \mathrm{CO}_{2} ; \\
\text { Ozone; } \mathrm{PM}_{2.5} ; \\
\mathrm{PM}_{10}, \mathrm{CO} ; \mathrm{HCHO}\end{array}$ & $\begin{array}{c}\text { Samplers; } \\
\text { polytetrafluoroethylene } \\
\text { membrane disks; } \\
\text { multiparametric probe } \\
\text { (model TG 502; GrayWolf } \\
\text { Sensing Solutions); }\end{array}$ & EPA; NIOSH & $\begin{array}{c}\text { Non-parametric } \\
\text { Mann-Whitney U } \\
\text { analysis; }\end{array}$ & $\begin{array}{l}\text { Indoor } \mathrm{CO}_{2} \text { and TVOCs are } \\
\text { significant than outdoor; } \\
\text { Ozone is formed by electronic } \\
\text { equipment (old printers and } \\
\text { photocopy machines; air } \\
\text { humidifier) and infiltration of } \\
\text { outdoor air; }\end{array}$ \\
\hline $\begin{array}{l}\text { Verriele et al., } 2016 \\
\text { [203] }\end{array}$ & France & School buildings & $\begin{array}{c}\mathrm{CO}_{2} ; \mathrm{TVOC} ; \\
\text { Ozone; } \mathrm{NO}_{2} ; \\
\text { Formaldehyde }\end{array}$ & $\begin{array}{c}\text { Radial-type diffusion } \\
\text { samplers; Radiello }{ }^{\circledR} 145 \\
\text { samplers }\end{array}$ & $\begin{array}{c}\text { Radial-type } \\
\text { diffusion samplers; } \\
\text { Radiello }{ }^{\circledR} 145 \\
\text { samplers }\end{array}$ & $\begin{array}{c}\text { Multiple } \\
\text { regression analysis }\end{array}$ & $\begin{array}{l}\text { Energy-efficient building and } \\
\text { the standard building has } \\
\text { similar IAQ conditions; } \\
\text { acetone, 2-butanone, } \\
\text { formaldehyde, acetaldehyde, } \\
\text { hexaldehyde, toluene, heptane, } \\
\text { and pentanal are the highest } \\
\text { concentrations been found of } \\
\text { VOCs; Strongly correlation } \\
\text { between acetone, butanone, } \\
\text { alkanes with occupants } \\
\text { activities. }\end{array}$ \\
\hline
\end{tabular}


Table 3. Cont

\begin{tabular}{|c|c|c|c|c|c|c|c|}
\hline Study & Location & Subject & Indicators & Measuring Tool & Standard & Analysis/Program & Main Results \\
\hline $\begin{array}{c}\text { Mainka et al., } 2015 \\
\text { [204] }\end{array}$ & $\begin{array}{l}\text { Gliwice, Poland } \\
\text { (Urban and Rural } \\
\text { Regions) }\end{array}$ & $\begin{array}{l}\text { Nursery schools; } \\
\text { Education } \\
\text { Buildings }\end{array}$ & $\begin{array}{c}\mathrm{PM}_{1}, \mathrm{PM}_{2.5}, \mathrm{PM}_{10} \\
\mathrm{CO}_{2}\end{array}$ & $\begin{array}{c}5 \mathrm{~mm} \text { Nuclepore } \\
\text { membranes;Teflon filters; } \\
\text { Whatman QMA filters; } \\
\text { automatic portable } \\
\text { monitors }\end{array}$ & $\begin{array}{c}\text { WHO and EU } \\
\text { Legislation; } \\
\text { ASHRAE; PN-EN } \\
13779\end{array}$ & $\begin{array}{l}\text { The Wilcoxon } \\
\text { paired sign rank } \\
\text { test }\end{array}$ & $\begin{array}{l}\text { Low efficiency of ventilation } \\
\text { systems caused high } \mathrm{CO}_{2} \text { and } \\
\text { PM concentration; } \\
\text { older children's classrooms } \\
\text { have higher PM concentration } \\
\text { than younger's classroom. } \\
\text { Teaching hours have the } \\
\text { highest IAQ concentrations; }\end{array}$ \\
\hline $\begin{array}{c}\text { Mainka et al., } 2015 \\
\text { [205] }\end{array}$ & Gliwice, Poland & Nursery schools & $\begin{array}{c}\mathrm{PM}_{1}, \mathrm{PM}_{2.5}, \mathrm{PM}_{10} \\
\mathrm{CO}_{2} ; \mathrm{VOCs}\end{array}$ & $\begin{array}{l}\text { Thermal desorber } \\
\text { TurboMatrix } 100 \\
\text { connected to a gas } \\
\text { chromatograph Clarus } \\
500 \text { with a flame } \\
\text { ionization detector }\end{array}$ & $\begin{array}{l}\text { WHO and EU } \\
\text { Legislation; } \\
\text { ASHRAE; PN-EN } \\
\text { 13779,12341; US } \\
\text { EPA TO-17 } \\
\text { method }\end{array}$ & $\begin{array}{c}\text { The Wilcoxon } \\
\text { paired sign rank } \\
\text { test, } \\
\text { Statistical package }\end{array}$ & $\begin{array}{l}\text { Indoor sources are the main } \\
\text { contributors of IAQ in } \\
\text { investigated schools; } \mathrm{CO}_{2} \\
\text { concentration reaches highest } \\
\text { after slept during the } \\
\text { afternoon; mitigation method } \\
\text { included: Improving } \\
\text { ventilation, decreasing the } \\
\text { occupancy per room, } \\
\text { modifying every-day vacuum } \\
\text { cleaning into wet cleaning; }\end{array}$ \\
\hline $\begin{array}{c}\text { Vassura et al., } 2015 \\
\text { [206] }\end{array}$ & Bologna, Italy & $\begin{array}{l}\text { School Building } \\
\text { (educational } \\
\text { institute, preschool } \\
\text { and elementary } \\
\text { Schools) }\end{array}$ & $\begin{array}{c}\mathrm{VOC} ; \mathrm{CO}_{2} ; \mathrm{CO} ; \\
\mathrm{NO}_{2}\end{array}$ & $\begin{array}{c}\text { Sensors: } \\
\text { Photoionization detector } \\
\text { (PID); (Q-Track) } \\
\text { non-dispersive infrared; } \\
\text { Electrochemical; } \\
\text { conductibility } \\
\text { detector (Metrohom, } 761 \\
\text { Compact IC) }\end{array}$ & WHO & $\begin{array}{l}\text { Pearson } \\
\text { correlation } \\
\text { analysis }\end{array}$ & $\begin{array}{l}\mathrm{CO}_{2} \text { comes mainly from } \\
\text { indoor; } \mathrm{CO}_{2} \text { and TVOC have } \\
\text { similar daily trend; }\end{array}$ \\
\hline $\begin{array}{c}\text { Sunyer et al., } 2015 \\
\text { [207] }\end{array}$ & Catalonia, Spain & Primary School & $\begin{array}{l}\mathrm{EC}, \mathrm{NO}_{2} \text {, and } \\
\text { ultrafine particle } \\
\text { number }\end{array}$ & $\begin{array}{c}\text { MicroAeth AE51 } \\
\text { (AethLabs) and DiSCmini } \\
\text { (Matter Aerosol) meters; } \\
\text { high-volume sampler } \\
\text { (MCV); passive tube } \\
\text { (Gradko) }\end{array}$ & WHO & $\begin{array}{c}\text { Spearman } \\
\text { Regression } \\
\text { Analysis }\end{array}$ & $\begin{array}{l}\text { Traffic-related air pollution is } \\
\text { associated with a smaller } \\
\text { increase in cognitive } \\
\text { development; Brain } \\
\text { development might be affected } \\
\text { by TRAP }\end{array}$ \\
\hline
\end{tabular}


Table 4. Air quality measurements and data analysis for residential buildings.

\begin{tabular}{|c|c|c|c|c|c|c|c|}
\hline Study & Location & Subject & Control Factor & Measuring Tool & Standard & $\begin{array}{l}\text { Analysis/ } \\
\text { Program }\end{array}$ & Main Results \\
\hline $\begin{array}{c}\text { Huang et al., } 2018 \\
\text { [208] }\end{array}$ & $\begin{array}{l}\text { Shenyang and } \\
\text { Fushun } \\
\text { Northeast China }\end{array}$ & $\begin{array}{l}\text { Six residential } \\
\text { buildings; } \\
21 \text { households }\end{array}$ & $\begin{array}{l}\mathrm{HCHO} ; \mathrm{VOCs} ; \\
\mathrm{PM}_{2.5} ; \mathrm{CO}_{2}\end{array}$ & $\begin{array}{c}\text { Spectrophotometer based } \\
\text { on phenol } \\
\text { reagent( } \mathrm{HCHO}) ; \\
\text { Gas } \\
\text { Chromatography-Mass } \\
\text { Spectrometry (VOCs); } \\
\text { Telaire } 7001 \mathrm{CO}_{2} \text { testers } \\
\left(\mathrm{CO}_{2}\right) ; \text { The } \mathrm{TSI}_{\text {particle }} \\
\text { tester }\left(\mathrm{PM}_{2.5}\right) ;\end{array}$ & $\begin{array}{l}\text { Chinese national } \\
\text { standard GB/T } \\
18204.2-2014\end{array}$ & $\begin{array}{c}\text { Pearson } \\
\text { correlation } \\
\text { analysis } \\
\text { (SPSS Ver.22); } \\
\text { Crystal Ball } \\
\text { software_Monte } \\
\text { Carlo simulation } \\
\text { (The health risk } \\
\text { analysis); }\end{array}$ & $\begin{array}{l}\text { Indoor } \mathrm{PM}_{2.5} \text { is closely } \\
\text { correlated with outdoor } \\
\text { contamination; } \mathrm{HCHO} \text { and } \\
\mathrm{CO}_{2} \text { were significantly and } \\
\text { correlated with the } \\
\text { window-opening duration; } \\
\text { TVOC had a positive } \\
\text { correlation with indoor RH\&T, } \\
\text { the surface area of furniture; } \\
\text { Outdoor } \mathrm{PM}_{2.5} \text { was } \\
\text { significantly correlated with } \\
\text { the building heating load }\end{array}$ \\
\hline $\begin{array}{c}\text { Zhao et al., } 2018 \\
\text { [209] }\end{array}$ & Tianjin, China & $\begin{array}{l}\text { Residential } \\
\text { dwelling }\end{array}$ & $\mathrm{PM}_{10} ; \mathrm{CO}_{2}$ & $\begin{array}{c}\mathrm{PM}_{2.5} \text {, sensor; } \\
\mathrm{CO}_{2} \text {, sensor; } \\
\text { power sensor } \\
\text { behavior recording } \\
\text { sensors(Xiaomi) }\end{array}$ & $\begin{array}{c}\text { Chinese National } \\
\text { Standard GB/T } \\
\text { 18883-2002; WHO }\end{array}$ & $\begin{array}{l}\text { Data batch } \\
\text { processing }\end{array}$ & $\begin{array}{l}\text { Outdoor particle concentration } \\
\text { and indoor activities affected } \\
\text { IAQ; Natural ventilation with } \\
\text { a portable air cleaner can } \\
\text { remove mass particle and } \\
\text { create good IAQ; }\end{array}$ \\
\hline $\begin{array}{c}\text { Liu et al., } 2018 \\
\text { [210] }\end{array}$ & Baoding, China & $\begin{array}{l}85 \text { residential } \\
\text { buildings }\end{array}$ & $\begin{array}{l}\text { Fungi; } \mathrm{PM}_{2.5} \\
\mathrm{PM}_{10} ; \mathrm{CO}_{2}\end{array}$ & $\begin{array}{c}\text { TIS 7515; } \\
\text { TIS 8520; } \\
\text { six-stage Anderson } \\
\text { impactor }\end{array}$ & N/A & $\begin{array}{c}\text { Single hidden } \\
\text { layer ANN models } \\
\text { with a } \\
\text { back-propagation } \\
\text { algorithm; } \\
\text { The }\end{array}$ & $\begin{array}{l}\text { The ANN model for airborne } \\
\text { culturable fungi reached } \\
83.33 \% \text { in the testing with } 30 \% \\
\text { tolerance }\end{array}$ \\
\hline $\begin{array}{c}\text { Quang et al., } 2017 \\
\text { [211] }\end{array}$ & Hanoi, Vietnam & $\begin{array}{l}\text { Residential } \\
\text { Houses }\end{array}$ & $\begin{array}{l}\text { Particle number } \\
\quad(\mathrm{PN}) ; \mathrm{PM}_{2.5}\end{array}$ & $\begin{array}{c}\text { Aerasense NanoTracers } \\
\text { (NTs); TSI model } 3787 \\
\text { Air quality monitoring } \\
\text { station }\end{array}$ & WHO & $\begin{array}{c}\text { Descriptive } \\
\text { statistics with } \\
\text { t-test and ANOVA } \\
\text { test }\end{array}$ & $\begin{array}{l}\mathrm{PM}_{2.5} \text { concentrations are not } \\
\text { indicative of the PN } \\
\text { concentrations; combustion } \\
\text { (traffic emission) sources are } \\
\text { the main contributor to PN } \\
\text { value; } \mathrm{PN} \text { concentrations } \\
\text { lower in dry weather; }\end{array}$ \\
\hline
\end{tabular}


Table 4. Cont.

\begin{tabular}{|c|c|c|c|c|c|c|c|}
\hline Study & Location & Subject & Control Factor & Measuring Tool & Standard & $\begin{array}{l}\text { Analysis/ } \\
\text { Program }\end{array}$ & Main Results \\
\hline $\begin{array}{c}\text { Du et al., } 2015 \\
\text { [212] }\end{array}$ & $\begin{array}{c}\text { Finland and } \\
\text { Lithuania }\end{array}$ & $\begin{array}{l}\text { Multi-family } \\
\text { buildings }\end{array}$ & $\begin{array}{c}\mathrm{CO}_{2} ; \mathrm{CO} ; \mathrm{PM}_{2.5} ; \\
\mathrm{PM}_{10} ; \mathrm{NO}_{2} ; \mathrm{VOCs} ; \\
\text { radon; } \\
\text { Formaldehyde }\end{array}$ & $\begin{array}{c}\text { HD21AB/HD21AB17, } \\
\text { Sensors; OPCs, Handheld } \\
\text { 3016 IAQ; } \\
\text { Difram100 Rapid air } \\
\text { monitor; Radiello } \\
\text { Cartridge Adsorbents }\end{array}$ & $\begin{array}{c}\text { WHO; EC; } \\
\text { Ministry of Social } \\
\text { Affairs and health, } \\
\text { "Finnish Housing } \\
\text { Health Guide"; } \\
\text { Lietuvos higienos } \\
\text { norma HN 35:2007 }\end{array}$ & $\begin{array}{c}\text { Spearman } \\
\text { correlation } \\
\text { Analysis; }\end{array}$ & $\begin{array}{l}\text { Different insulation and } \\
\text { ventilation system could be the } \\
\text { primary reasons for the IAQ } \\
\text { Concentrations; mechanical } \\
\text { ventilation provides lower } \\
\text { IAQ concentrations and } \\
\text { infiltration of outdoor source; }\end{array}$ \\
\hline $\begin{array}{c}\text { Meier et al., } 2015 \\
\text { [213] }\end{array}$ & $\begin{array}{l}\text { Basel, Geneva, } \\
\text { Lugano, } \\
\text { Switzerland }\end{array}$ & Residential, House & $\begin{array}{c}\text { UFP, } \mathrm{PM}_{10}, \mathrm{PM}_{2.5} \\
\mathrm{PMabsorbance} \\
\text { and } \mathrm{NO}_{2} .\end{array}$ & $\begin{array}{c}37 \mathrm{~mm} \text { Teflon filters (Pall } \\
\text { Corporation); One MEDO } \\
\text { vacuum } \\
\text { pump VP0125 (MEDO } \\
\text { USA); passive diffusion } \\
\text { samplers (Passam AG); }\end{array}$ & EPA; & $\begin{array}{l}\text { Pearson, } \\
\text { STATA }\end{array}$ & $\begin{array}{c}\text { The site allowed tobacco } \\
\text { smoke had higher I/O value; } \\
\text { Outdoor } \\
\text { Concentrations associated } \\
\text { with traffic conditions; PNC } \\
\text { levels showed highest during } \\
\text { lunchtime; PMabsorbance, the } \\
\text { lowest for PNC and PMcoarse } \\
\text { showed the highest } \\
\text { correlation; }\end{array}$ \\
\hline
\end{tabular}

Table 5. Air quality measurements and data analysis for other types of buildings.

\begin{tabular}{|c|c|c|c|c|c|c|c|}
\hline Study & Location & Subject & Control Factor & Measuring Tool & Standard & Analysis/Program & Main Results \\
\hline $\begin{array}{c}\text { Kim et al., } 2019 \\
\text { [214] }\end{array}$ & Seoul, Korea & Commercial office & $\mathrm{CO}_{2} ; \mathrm{PM}_{2.5} ; \mathrm{PM}_{10}$ & $\begin{array}{l}\text { Wireless sensor: } \\
\text { Wiseairsense } \\
\text { (Wifi-Sensor) } \\
\text { BR-Smart-126 } \\
\text { (micro-SD Sensor) }\end{array}$ & $\begin{array}{l}\text { ASHRAE A.N.S.I } \\
\text { 55-2004; 62.1; } \\
\text { EPA-Air Quality } \\
\text { Criteria for } \\
\text { Particulate Matter; } \\
\text { Standardized EPA } \\
\text { Protocol for } \\
\text { Characterizing } \\
\text { Indoor Air Quality } \\
\text { in Large Office } \\
\text { Buildings }\end{array}$ & $\begin{array}{l}\text { Multivariate } \\
\text { analysis of } \\
\text { variance } \\
\text { (MANOVA) } \\
\text { Pearson } \\
\text { correlation } \\
\text { analysis }\end{array}$ & $\begin{array}{l}\text { A non-woven fabric filter } \\
\text { resulted in poor indoor air } \\
\text { quality due to high resistance } \\
\text { to flow (room A) and an } \\
\text { electrostatic filter improved } \\
\text { indoor air quality (room B) }\end{array}$ \\
\hline $\begin{array}{c}\text { Roshan et al., } 2019 \\
\text { [215] }\end{array}$ & Tehran, Iran & $\begin{array}{c}\text { Children's Medical } \\
\text { Center }\end{array}$ & $\begin{array}{c}\text { Fungal } \\
\text { bio-aerosols }\end{array}$ & Sampler & NIOSH & $\begin{array}{l}\text { One-way ANOVA } \\
\text { followed by post } \\
\text { hoc Scheffe's test. }\end{array}$ & $\begin{array}{l}\text { The indoor fungal bio-aerosols } \\
\text { may have originated from the } \\
\text { outdoor environment }\end{array}$ \\
\hline
\end{tabular}


Table 5. Cont.

\begin{tabular}{|c|c|c|c|c|c|c|c|}
\hline Study & Location & Subject & Control Factor & Measuring Tool & Standard & Analysis/Program & Main Results \\
\hline $\begin{array}{c}\text { Tolis et al., } 2019 \\
\text { [216] }\end{array}$ & Kozani, Greece & An aquatic center & $\begin{array}{c}\mathrm{PM}_{2.5} ; \mathrm{NO}_{2} ; \mathrm{O}_{3} ; \\
\text { VOCs }\end{array}$ & $\begin{array}{l}\text { 47-mm quartz fiber filters; } \\
\text { Low Volume Air } \\
\text { Sampling Systems } \\
\text { (Derenda } \\
\text { LVS3.1/PMS3.1-15 and }^{\text {Teccora with a PM }} \text { P.5 } \\
\text { inlet); AEROQUAL } \\
\text { (Series 500 IAQ) }\end{array}$ & WHO & $\begin{array}{l}\text { TD-GC-MS } \\
\text { analysis }\end{array}$ & $\begin{array}{l}\text { Indoor } \mathrm{PM}_{2.5} \text { in the aquatic } \\
\text { center is mainly influenced by } \\
\text { outdoor climatic conditions } \\
\text { and pollutant concentrations; } \\
\text { Indoor } \mathrm{NO}_{2} \text { value is higher } \\
\text { than outdoor due to indoor } \\
\text { transport phenomena and } \\
\text { combustion sources; Outdoor } \\
\mathrm{O}_{3} \text { higher than Indoor. }\end{array}$ \\
\hline $\begin{array}{c}\text { Hwang et al., } 2018 \\
\text { [217] }\end{array}$ & $\begin{array}{l}\text { Seoul, } \\
\text { Korea }\end{array}$ & $\begin{array}{l}82 \text { indoor-facilities } \\
\text { (hospitals, geriatric } \\
\text { hospitals, elderly } \\
\text { care facilities, and } \\
\text { postnatal care } \\
\text { centers) }\end{array}$ & $\begin{array}{c}\mathrm{PM}_{10} ; \mathrm{CO}_{2} ; \\
\text { airborne bacteria } \\
\text { (AB); TVOCs; } \\
\text { Formaldehyde }\end{array}$ & $\begin{array}{l}\text { Sampler SARA-4100; } \\
\text { Microbial one-stage Buck } \\
\text { Bio-Culture sampler; } \\
\text { 2,4-dinitrophenylhydrazine } \\
\text { cartridge and an MP- } \Sigma 100 \\
\text { pump; UV-VIS detector; } \\
\text { Tenax-TA tubes; MP- } \Sigma 30\end{array}$ & $\begin{array}{l}\text { Korean IAQ } \\
\text { standard }\end{array}$ & $\begin{array}{c}\text { Spearman's } \\
\text { correlation; } \\
\text { Whitney analyses; }\end{array}$ & $\begin{array}{l}\text { A significant correlation } \\
\text { between indoor temperature } \\
\text { and } \mathrm{AB} \text { concentration, TVOCs, } \\
\text { Formaldehyde. Indoor } \mathrm{PM}_{10} \\
\text { was higher than Outdoor } \\
\text { concentration in all facilities. }\end{array}$ \\
\hline $\begin{array}{c}\text { Deng et al., } 2017 \\
\text { [218] }\end{array}$ & Beijing, China & $\begin{array}{l}\text { Public buildings } \\
\text { (basketball } \\
\text { stadium, hotel, } \\
\text { a shopping center, } \\
\text { research center } \\
\text { and commercial } \\
\text { office and two } \\
\text { residential homes) }\end{array}$ & $\mathrm{PM}_{2.5}$ & TSI 8530 instrument & $\begin{array}{l}\text { Chinese standard, } \\
\text { “Indoor-air-quality } \\
\text { standard } \\
\text { (GB/T18883-2002) }\end{array}$ & $\begin{array}{c}\text { Linear regression } \\
\text { analysis }\end{array}$ & $\begin{array}{c}\text { Indoor } \mathrm{PM}_{2.5} \text { mainly } \\
\text { associated with the outdoor } \\
\text { source; the natural } \\
\text { Ventilation is more effective to } \\
\text { reduce the } \mathrm{PM}_{2.5} \\
\text { Concentration; Ventilation } \\
\text { system with fan-coil air } \\
\text { cleaning system can remove } \\
\text { approximately } 90 \% \text { of outdoor } \\
\text { particles; }\end{array}$ \\
\hline $\begin{array}{c}\text { Saraga et al., } 2017 \\
\text { [219] }\end{array}$ & Doha, Qatar & An office building & $\begin{array}{l}\mathrm{PM}_{2.5} \\
\mathrm{PM}_{10}\end{array}$ & $\begin{array}{c}\text { Samplers (LVS16 by WB } \\
\text { Engineering } \\
\text { GmbH) }\end{array}$ & $\begin{array}{l}\text { WHO; EN } \\
12341: 2014\end{array}$ & $\begin{array}{l}\text { Pearson } \\
\text { correlation } \\
\text { analysis; } \\
\text { IBM SPSS }\end{array}$ & $\begin{array}{l}\text { Outdoor and Indoor PM } \\
\text { concentrations were } \\
\text { significantly lower when } \\
\text { reduced indoor activities; } \\
\text { traffic-related sources and } \\
\text { re-suspended dust were } \\
\text { associated with OC/EC value; } \\
\text { a positive correlation between } \\
\text { indoor and outdoor pm and } \\
\text { PM concentrations when } \\
\text { HVAC in operation; }\end{array}$ \\
\hline
\end{tabular}


Table 5. Cont

\begin{tabular}{|c|c|c|c|c|c|c|c|}
\hline Study & Location & Subject & Control Factor & Measuring Tool & Standard & Analysis/Program & Main Results \\
\hline $\begin{array}{c}\text { Loupa et al., } 2016 \\
{[220]}\end{array}$ & Kavala, Greece & Hospital & $\mathrm{PM}_{2.5} ; \mathrm{CO}_{2}, \mathrm{BC} ;$ & $\begin{array}{c}\text { Sampler (90 mm diameter } \\
\text { Dichotomous Stack Filter } \\
\text { Units); Gas Card II, } \\
\text { infrared gas monitor; } \\
\text { Particle Soot Absorption } \\
\text { Photometer; LASAIR } \\
\text { Model 5295 }\end{array}$ & $\begin{array}{c}\text { EN 13779, 2007; } \\
\text { EN 779, 2012; } \\
\text { WHO }\end{array}$ & $\begin{array}{l}\text { Pearson } \\
\text { correlation } \\
\text { analysis }\end{array}$ & $\begin{array}{c}\text { Indoor concentrations of } \\
\mathrm{PM}_{2.5}, \mathrm{BC} \text {, and } \mathrm{CO}_{2} \text { were } \\
\text { showed positively correlated; } \\
\text { The average } \mathrm{I} / \mathrm{O} \mathrm{PM}_{2.5} \text { ratios } \\
\text { are less than one; } \mathrm{PM}_{2.5} \text { and } \\
\mathrm{BC} \text { were strongly related to the } \\
\text { outdoor value; } \mathrm{PM} \text { increased } \\
\text { in all particle sizes }\end{array}$ \\
\hline $\begin{array}{c}\text { He et al., } 2016 \\
\text { [221] }\end{array}$ & $\begin{array}{l}\text { Guangdong, } \\
\text { China }\end{array}$ & Hotel buildings & $\begin{array}{c}\mathrm{CO}_{2} ; \mathrm{CO} ; \mathrm{PM}_{10} \\
\mathrm{PM}_{2.5} ; \mathrm{VOCs}\end{array}$ & $\begin{array}{c}\text { HP } 6890 \text { gas } \\
\text { chromatograph/5973 mass } \\
\text { selective detector; samples } \\
\text { (Air-Check-52, (DC-LITE), } \\
\text { portable analyzers, } \\
\text { portable Q-Trak monitors } \\
\text { (Model } 8551 \text { and } 8520 \text { ) }\end{array}$ & $\begin{array}{l}\text { EPA method To-17; } \\
\text { Chinese indoor air } \\
\text { quality standard } \\
\text { (IAQS); ASHRAE }\end{array}$ & $\begin{array}{l}\text { Regression } \\
\text { Analysis; } \\
\text { PCA; }\end{array}$ & $\begin{array}{l}\text { Occupants' activities were the } \\
\text { main source of } \mathrm{PM}_{10}, \mathrm{PM}_{2.5} \\
\text { concentrations; building } \\
\text { materials, outdoor sources, } \\
\text { human activities, cleaning } \\
\text { products, and human } \\
\text { respiration are the main source } \\
\text { of indoor pollutants; }\end{array}$ \\
\hline $\begin{array}{c}\text { Irga et al., } 2016 \\
\text { [222] }\end{array}$ & Sydney, Australia & Office buildings & $\begin{array}{c}\mathrm{CO}_{2} ; \mathrm{CO} ; \mathrm{SO}_{2} ; \\
\text { VOCs; } \mathrm{PM}_{10} \\
\mathrm{PM}_{2.5} ; \text { Total } \\
\text { suspended } \\
\text { particulate matter; } \\
\text { VOCs; Airborne } \\
\quad \text { fungi }\end{array}$ & $\begin{array}{l}\text { Yessair 8-channel IAQ } \\
\text { Monitor (Critical } \\
\text { Environment } \\
\text { Technologies); DustTrack } \\
\text { II Aerosol Monitor } 8532 \\
\text { laser densitometer. a } \\
\text { GasAlert Extreme } \\
\text { T2A-7X9; a Reuter } \\
\text { Centrifugal air } \\
\text { sampler(RGS). }\end{array}$ & $\begin{array}{l}\text { WHO; ISIAQ; } \\
\text { ACGIH; AIHA }\end{array}$ & $\begin{array}{c}\text { Univariate data } \\
\text { analysis } \\
\text { multivariate } \\
\text { analysis; } \\
\text { General linear } \\
\text { model ANOVA; } \\
\text { analyses of } \\
\text { similarities } \\
\text { (ANOSIM) using a } \\
\text { 4th root } \\
\text { transformation } \\
\text { and the } \\
\text { construction of a } \\
\text { Euclidean distance } \\
\text { similarity matrix; } \\
\text { Similarity } \\
\text { percentages } \\
\text { analysis (SIMPER) }\end{array}$ & $\begin{array}{l}\text { MVS buildings recorded the } \\
\text { lowest PM and Airborne fungi; } \\
\mathrm{NV} \text { buildings and CVS } \\
\text { buildings observed highest } \\
\mathrm{NO}_{2} ; \mathrm{MVS} \text { showing higher } \\
\mathrm{CO}_{2} \text { than others; }\end{array}$ \\
\hline
\end{tabular}


Table 5. Cont

\begin{tabular}{|c|c|c|c|c|c|c|c|}
\hline Study & Location & Subject & Control Factor & Measuring Tool & Standard & Analysis/Program & Main Results \\
\hline $\begin{array}{c}\text { Shang et al., } 2016 \\
\text { [223] }\end{array}$ & Western China & Shopping mall & $\begin{array}{l}\mathrm{CO}_{2} \text {; TVOC; } \\
\text { Formaldehyde; }\end{array}$ & $\begin{array}{l}\text { Kanomax 6531; } \\
\text { Telaire 7001; } \\
\text { PGM-7240 ppb RAE; }\end{array}$ & $\begin{array}{c}\text { China Energy } \\
\text { Efficiency Testing } \\
\text { of Public Buildings } \\
\text { Standard (JGJ.T } \\
\text { 177-2009; } \\
\text { Formaldehyde } \\
\text { 400; China Indoor } \\
\text { Air Standard } \\
\text { (GB/T 18883-2002) }\end{array}$ & $\begin{array}{l}\text { Spearman rank } \\
\text { correlation; } \\
\text { Multiple } \\
\text { Regression } \\
\text { Analysis }\end{array}$ & $\begin{array}{l}\text { A strong correlation of } \\
\text { customer flow rate with TVOC } \\
\text { and } \mathrm{CO}_{2} \text {; pre-ventilation rate } \\
\text { decreased the first-hour } \\
\text { formaldehyde concentrations }\end{array}$ \\
\hline $\begin{array}{c}\text { Hu et al., } 2015 \\
\text { [224] }\end{array}$ & $\begin{array}{l}\text { Yangtze River } \\
\text { Region, China }\end{array}$ & Museums & $\begin{array}{l}\mathrm{NO}_{2} ; \mathrm{SO}_{2} ; \mathrm{O}_{3} \\
\mathrm{PM}_{2.5} ; \mathrm{PM}_{10}\end{array}$ & $\begin{array}{c}\text { Q-Trak Plus IAQ monitors } \\
\text { (Model 7565, 4150, 4240, } \\
\text { 4480); mini-vol portable } \\
\text { sampler; TSI 8520; }\end{array}$ & ASHRAE 2011; & N/A & $\begin{array}{l}\text { In certain seasons, } \\
\text { Investigated buildings are not } \\
\text { able to effectively against } \\
\text { outdoor air pollutants. } \\
\text { Mechanical ventilation } \\
\text { equipped system had better } \\
\text { perform on IAQ control; }\end{array}$ \\
\hline $\begin{array}{c}\text { Montgomery et al., } \\
2015 \\
{[225]}\end{array}$ & $\begin{array}{l}\text { Vancouver, } \\
\text { Canada }\end{array}$ & OfficeBuilding & $\begin{array}{c}\mathrm{PM}_{10}, \mathrm{PM}_{2.5} ; \mathrm{PM}_{1} \\
\text { TVOCs; } \mathrm{CO}_{2}\end{array}$ & $\begin{array}{c}\text { TSI aps 3321; } \\
\text { Tsi Velocicalc 8386; } \\
\text { PPBrae pgm-7240; } \\
\text { Honeywell c7632; } \\
\text { Omega px274-05di; }\end{array}$ & $\begin{array}{c}\text { ASHRAE } \\
\text { Standard 62.1-2010 }\end{array}$ & $\begin{array}{l}\text { Pearson } \\
\text { correlations } \\
\text { analysis }\end{array}$ & $\begin{array}{l}\text { The mechanical ventilation } \\
\text { effectively control the TVOCs } \\
\text { and } \mathrm{CO}_{2} \text { regardless of } \\
\text { occupant load; natural } \\
\text { ventilation difficult to achieve } \\
\text { standard flow rate; Ventilation } \\
\text { scheduling significantly } \\
\text { impact on indoor gas } \\
\text { concentrations; The ventilation } \\
\text { system should work before } \\
\text { occupants arrival and } \\
\text { shutdown after room empty } \\
\text { and the IAQ reach the } \\
\text { standard level; }\end{array}$ \\
\hline
\end{tabular}


Table 5. Cont.

\begin{tabular}{|c|c|c|c|c|c|c|c|}
\hline Study & Location & Subject & Control Factor & Measuring Tool & Standard & Analysis/Program & Main Results \\
\hline $\begin{array}{l}\text { Challoner et al., } \\
2015 \\
{[226]}\end{array}$ & Dublin, Ireland & $\begin{array}{l}\text { Commercial } \\
\text { Buildings }\end{array}$ & $\mathrm{PM}_{2.5} ; \mathrm{NO}_{2}$ & $\begin{array}{c}\text { (Environmental Devices } \\
\text { Corporation, EPAM-5000, } \\
\text { Haz-Dust; an M200E } \\
\text { model; }\end{array}$ & WHO & $\begin{array}{c}\text { The } \\
\text { Personal-exposure } \\
\text { Activity Location } \\
\text { Model (PALM); } \\
\text { Artificial } \\
\text { Neural Networks; } \\
\text { The } \\
\text { Levenberg-Marquardt } \\
\text { Algorithm (LMA); } \\
\text { the Gauss-Newton } \\
\text { Algorithm; } \\
\text { "Neural Network } \\
\text { Time-series Tool" } \\
\text { using a non-linear } \\
\text { auto-regression } \\
\text { with external input } \\
\text { networks (NARX) } \\
\text { modeling } \\
\text { technique; Pearson } \\
\text { correlation } \\
\text { Analysis }\end{array}$ & $\begin{array}{l}\text { The ANN modeling showed } \\
\mathrm{PM}_{2.5} \text { data with a larger range } \\
\text { of errors and lower Pearson's } \\
\mathrm{R} \text { values for regressions. The } \\
\text { model had better performance } \\
\text { on Indoor } \mathrm{NO}_{2} \text { than } \mathrm{PM}_{2.5}\end{array}$ \\
\hline $\begin{array}{c}\text { Kwon et al., } \\
2015 \\
{[227]}\end{array}$ & Seoul, Korea & $\begin{array}{l}\text { Metropolitan } \\
\text { Subway Stations }\end{array}$ & $\begin{array}{c}\mathrm{PM}_{10} ; \mathrm{PM}_{2.5} ; \mathrm{PM}_{1} \\
\mathrm{CO}_{2}\end{array}$ & $\begin{array}{l}\text { Optical particle sizer } \\
\text { (OPS; TSI model 3330) }\end{array}$ & WHO; ASHRAE & $\begin{array}{c} \\
\text { PCA; } \\
\text { Non-parametric } \\
\text { Kolmogorov-Smirnov } \\
\text { test; } \\
\text { Self-Organizing } \\
\text { Feature Mapping } \\
\end{array}$ & $\begin{array}{l}\text { Seasonal variable was the } \\
\text { most significant factor when } \\
\text { categorizing the data groups; } \\
\text { PM size fraction was highly } \\
\text { influenced by the air } \\
\text { ventilation rate and depth of } \\
\text { the stations; Outdoor } \mathrm{PM}_{10} \text { if } \\
\text { the main source of indoor } \\
\text { PM }_{10} \text {; Trains volume was } \\
\text { associated with Indoor PM } \\
\text { platforms; }\end{array}$ \\
\hline
\end{tabular}


Analysis of the Sources and Mechanisms Affecting the Concentration Measurements

The identification of the determinant factors and mechanisms affecting the indoor air quality relies on data analysis techniques and quantifiable data, such as the time series concentrations collected from the monitoring equipment, potential building defects, ventilation specifications, and sometimes local meteorological data, occupancy activities, traffic volumes and other information [228]. Descriptive statistics with trends and graphic analysis are commonly used in observational studies. They provide summaries of the initial air quality measures by describing the data's central tendency, dispersion, variability, outliers, typos, and ranges, and the time-weighted average of the concentration levels [229-233]. Correlation analysis is often used for the evaluation of the association of the indoor and outdoor concentrations, as well as other related time-series data [17,220,234,235]. Typically, the linear relationship between two types of air pollutants is obtained by conducting parametric tests, i.e., $t$-tests, ANOVA, and Pearson correlations [219,220]. For the non-parametric studies, Spearman's correlation test has often been applied in order to examine the monotonic relationship between ordinal and binary variables, such as age, sex, health performance, and the degree of building-related defects $[195,210,212,217,223]$. When dealing with the observational data, which are non-normally distributed, non-parametric tests—such as Mann-Whitney-Wilcoxon and Kruskal-Wallis - can be used to evaluate the difference between the average of the measured exposure variables and ordinal variables $[195,202,219,236]$. On the other hand, earlier field studies have found significant multicollinearity problems and temporal cross-correlations between the measured ambient air pollutants and the related influence factors [62,237-240]. Very few studies, however, also considered the complex and nonlinear characters of indoor air pollutants [200,221,227]. Kwon et al. [227], using the principal component analysis (PCA) and self-organizing map (SOM) techniques, determined the dominant factors which increase indoor PM concentration by reducing the original set of inter-correlated variables and transforming them into principle component groups that are mutually orthogonal, or uncorrelated. Madureira et al. [200] and He et al. [221], mitigated the multicollinearity problems between the measured IAQ $\left(\mathrm{CO}_{2}, \mathrm{PM}_{2.5}, \mathrm{PM}_{10}\right.$, and VOCs), building characteristics, and occupant activities by conducting categorical PCA (dimensionality reduction method) with a varimax rotation approach [200]. Furthermore, the mixed-effect linear regression model with random intercept provides a flexible approach to assess the association between time-series concentrations and building-related categorical variables in field measurement studies. [213,227].

\section{Discussions}

\subsection{Air Quality Guidelines}

At present, there are several guidelines available around the world to prevent IAQ issues for different kinds of management decisions and planning processes. In most of developed or developing countries, they have and follow their respective local guidelines. The main air quality guidelines-which were reviewed in Section 4-are constantly being updated for more precise results in order to protect the target population. In spite of these efforts, the values of the guidelines are still different among each other due to many factors, such as the difference in the standard operating procedures, enforcement levels, and different design principles. Furthermore, there are various misconceptions about the interpretation of these values and guideline principles, which lead to misquotations by researchers and decision-makers. Most of the values which are represented in Table 3 are currently unenforceable because of the limited data availability, challenging deployment, and non-scalability of conventional air pollution tools such as FRM/FEM instruments. This situation is more prominent in indoor environment-related guidelines. There is also a lack of clear evidence on the exposure relevance of a different range of certain concentration values for the improvement of these guidelines, especially for the high-risk population. Log-term cluster randomized control trials and joint health impact assessment should be investigated for the development of future air quality standards. 


\subsection{Air Quality Sensors}

In this sub-section, we discuss the critical support of LCAQS in today's world, as well as their low-cost vs. their measurement accuracies. Besides this, we also discuss the technologies used to connect and transfer data from LCAQS.

\subsubsection{LCAQS}

Air quality sensor technology is an expeditiously growing field that has the key potential to improve the applicability, reliability, and cost-effectiveness of time-resolved air pollution measurements [84,90,241,242]. Many Low-Cost Air Quality Sensors (LCAQS) products are off-the-shelf, open-source, and are becoming increasingly available on the market. Except for technical inconvenience, the information on service life maintenance and durability are insufficient in the datasheet for most of the sensors. In the US, as per the existing literature, the average cost of LCAQS for $\mathrm{CO}, \mathrm{CO}_{2}, \mathrm{NO}_{2}, \mathrm{SO}_{2}$, ozone, TVOC, and PM ranges between $\$ 1$ and $\$ 500$, as of April 2020. There are several advantages of LCAQS besides their lower purchase and operation costs compared to regulatory-grade instruments, such as their higher spatial density; their greater number of options in the time-resolution of their data reporting; and their easier field deployment, data collection, and transmissions [90,243,244].

\subsubsection{Cost vs. Accuracy of the LCAQS}

In most cases, the measurement performance characteristics-such as the typical detection range, measurement tolerance or repeatability, data resolution, linearity, heat resistance, heater current, operating conditions, circuit condition, response time, supply voltage, supply current, and cross-sensitivity to other gases-are contained in the manufacturer's specifications of the LCAQS products. Even so, these performance indicators can vary from sensor to sensor, depending on the laboratory protocol applied, the test chamber set-up, the reference instrument used, the length of the observation period, the range of desired concentrations covered, the efficiency of the calibration algorithm, and the post-processing and data modeling [90,224-248].

\subsubsection{Technology of LCAQS}

According to the US EPA, LCAQS technology is not considered to be mature enough to be implemented for regulatory or compliance purposes at a mass scale [83], due to their limitations of robustness and repeatability, and the lack a widely-accepted protocol for the testing and utilization of these technologies [83,247-249]. Only limited numbers of the LCAQS developed are integrated with software and operational interface; most of the available program is only applied for a specific OS such as windows, android, and Linux, which increased the limits of openness. Some of LCAQS are designed to interconnect with smart equipment using Internet of Things (IoT) platforms.

\subsubsection{Performance Evaluation of LCAQS}

Numerous studies have assessed LCAQS, and can provide useful information on ambient gas species and mass particles in the range of specific conditions [79,91,92,245,250]. However, there is still no standard protocol for the evaluation of the performance and effectiveness of LCAQS against traditional monitoring equipment, such as FRM or FEM monitors, at present. In order to address these issues, three notable programs have been launched to quantitatively evaluate the performance of commercially available LCAQS compared to the high-precision equipment under both laboratory and field conditions. These are the AQ-SPEC operated by SCAQMD [251], the US EPA, Air Sensor Toolbox [252], and the EU JRC [253,254]. These platforms created opportunities to assess the data quality and stability of LCAQS by providing state-of-the-art equipment, such as a characterization chamber system, a zero-air generation system, a dynamic dilution calibrator, an air monitoring station, and the best available reference instruments $[116,245,251]$. 


\subsubsection{Uncertainties in LCAQS}

According to the reported results from the AQ-SPEC and the literature, the measurement uncertainty of all types of LCAQS is observed due to changes in the temperature, the relative humidity, cross-sensitivity, interfering compounds, and electronic component tolerances [89,90,253-256]. There is also uncertainty due to the sensors' calibration and synchronization errors in both the fine particle sensors and gas-phase sensors $[90,248,255]$. The proper calibration and normalization methods for each sensor need validation through the removal of structure errors between the measured and expected sensor output. Uncertainty and ambiguity can propagate through the description of the sensor data, the sampling of the sensor data, co-location experiments, the placement of the sensor, aerosol concentrations, errors in the running code, data recovery, and inference with the results [255,257-260]. The evaluations found that most $\mathrm{PM}_{2.5}$ and $\mathrm{PM}_{10}$ sensors showed strong correlations $\left(0.85<\mathrm{R}^{2}<0.99\right)$ in the laboratory test, and moderate to strong correlations $\left(0.52<R^{2}<0.99\right)$ in the field test with the BAM and FEM equipment (at the average range between 0 to $300 \mu \mathrm{g} / \mathrm{m}^{3} \neg$ ). The laboratory results also showed extremely low intra-model variability in data recovery ( $98 \%$ to $100 \%$ ), and RHT had minimal effects on the sensors' precision [84,90,246,261-265]. In contrast, most low-cost gas sensors (CO, $\mathrm{NO}_{2}$, and ozone) showed more inter-sensor variability than the fine-partial sensors, especially in the field test. Variations exist from sensor to sensor $\left(0.1<R^{2}<0.99\right)$, with a fair to good range of data recovery $(85 \%$ to $100 \%)$. The uncertainty of gas-phase sensors is generally associated with cross-sensitivity to ambient concentrations, out-of-range detection, spatiotemporal variations, and RHT conditions in the field environment $[245,260,266-269]$. To date, there are limited valid $\mathrm{SO}_{2}$ sensor evaluation reports available, for which this paper finds a curb on the provision of an overall status of $\mathrm{SO}_{2}$ conditions. According to the DQOs defined by the European Air Quality Directive, a maximum measurement uncertainty of $15 \%$ should not be exceeded for $\mathrm{O}_{3}, \mathrm{NO}_{2}$, $\mathrm{NOx}$, and $\mathrm{CO}$ sensors [191,221,222].

\subsubsection{QA/QC Control}

Quality Assessment/Quality Control (QA/QC) protocols must systematically be conducted in order to validate the data quality by considering the elimination of obvious outliers, negative values, and invalid data points $[90,259,266]$. In addition, the following methods should also be taken into account when performing the field measurement. These are: (a) repeated field calibration along with the combination of different sources in a multi-sensor data fusion algorithm [270-273] (b): sensitivity analysis [274,275] (c): Monte Carlo simulation methods [276-279] (d): the mathematical modeling of the error propagation. In concert, it is not mandatory to test the existing LCAQS in these evaluating platforms as well as both the sensor and testing enterprises executed through the optional registration system. This has caused these platforms to selectively recognize a sensor type or its particular parts, resulting in the production of an incomplete evaluation of the products' features and characterizations for the end-users. Currently, these sensor testing programs are being amended on their evaluation system, along with their testing protocols being improved, in order to provide more desired results. However, several of these sensor companies prefer to choose self-evaluation or the general international organization for product standardization. Finally, this study is an extensive review of the integrated sensor system which analysed the characteristics based on various factors, in order to examine indoor and outdoor air quality for the built environment. Therefore, such examinations elaborate on the importance of sensing systems to the monitoring of holistic air quality and the mitigation of pollution levels by impacting the occupants' health levels.

\section{Conclusions}

Human health is adversely impacted by indoor air pollutants. Various international agencies have incessantly developed quantitative air quality guidelines and standards to meet the requirements for proper indoor air quality management. This paper set out to gain a better understanding of the existing major standards and guidelines related to indoor air pollutants and their health impacts. The different 
limiting range for the identified pollutants, enforcement levels, applicable people, and operating procedures of each was reviewed. For the large-scale implementation of air quality management, this study indicates that the importance of monitoring air quality, in real-time, at spatial and temporal data resolutions cannot be understated. Furthermore, this paper also reviewed the existing LCAQS technologies, and discussed the corresponding specifications, such as the typical detection range, measurement tolerance or repeatability, data resolution, response time, supply current, and market price. LCAQS have changed the paradigm of indoor air pollution monitoring, and can provide beneficial information. This technology is not considered advanced enough to be implemented for regulatory purposes ata large scale, due to the limitations of their robustness, repeatability, and lack of a widely-accepted protocol for testing and utilization. Compared to the fine particulate matter sensors, gaseous sensors generally perform with added uncertainties and data variation. There is a need for unified industry-standard QA/QC protocols to analyze and validate overall LCAQS performance. Conclusively, this systematic review addressed the requirements of future research and design practices in order to protect occupants' health and achieve optimal indoor environmental quality.

Author Contributions: Conceptualization: H.Z. and R.S.; Writing—original draft: H.Z.; writing—review and editing: R.S.; supervision: R.S. All authors have read and agreed to the published version of the manuscript.

Funding: This research received no external funding.

Conflicts of Interest: The authors declare no conflict of interest.

\section{Abbreviations}

$\begin{array}{ll}\text { ACGIH } & \text { American Conference of Governmental Industrial Hygienists } \\ \text { ALA } & \text { American Lung Association } \\ \text { AQ-SPEC } & \text { Air Quality Sensor Performance Evaluation Center } \\ \text { ASHRAE } & \text { American Society of Heating, Refrigerating and Air-Conditioning Engineers } \\ \text { BASE } & \text { Building Assessment Survey and Evaluation } \\ \text { CARB } & \text { California Air Resources Board } \\ \text { CAAQS } & \text { California ambient air quality standards } \\ \text { SCAQMD } & \text { South Coast Air Quality Management District } \\ \text { COPD } & \text { chronic obstructive pulmonary disease } \\ \text { CDC } & \text { Centers for Disease Control and Prevention } \\ \text { CO } & \text { Carbon Monoxide } \\ \text { CO } 2 & \text { Carbon Dioxide } \\ \text { DOL } & \text { Department of Labor } \\ \text { DQOS } & \text { Data Quality Objectives } \\ \text { EC } & \text { Electrochemical } \\ \text { EU JRC } & \text { European Union Joint Research Centre } \\ \text { FEM } & \text { Federal Equivalent Methods } \\ \text { FRM } & \text { Federal Reference } \\ \text { HVAC } & \text { heating, ventilating and air-conditioning } \\ \text { IAQ } & \text { indoor air quality } \\ \text { LCAQS } & \text { Low-cost air quality sensors } \\ \text { MOS } & \text { Metal Oxide Semiconductor Sensors } \\ \text { MPI } & \text { Mass Psychogenic Illness } \\ \text { NAAQS } & \text { Ambient Air Quality Standards } \\ \text { NDIR } & \text { Non-dispersive Infrared Sensors } \\ \text { NIOSH } & \text { National Institute for Occupational Safety and Health } \\ \text { NO } & \text { Nitrogen Dioxide } \\ \mathrm{O}_{3} & \text { Ozone } \\ \text { OPC } & \text { Optical Particle Counters } \\ \text { OSHA } & \text { Occupational Safety and Health Administration } \\ \text { PCA } & \text { Principal components analysis } \\ \text { PID } & \text { Photo-ionization Detection Sensors } \\ & \end{array}$


PM

SBS

$\mathrm{SO}_{2}$

$\mathrm{TLVs}^{\circledR}$

TVOCs

$\mathrm{WHO}$
Particulate Matter

Sick Building Syndrome

Sulfur Dioxide

Threshold Limit Values

Total Volatile Organic Compounds

World Health Organization

\section{References}

1. WHO. Ambient Air Pollution: A Global Assessment of Exposure and Burden of Disease; World Health Organization: Geneva, Switzerland, 2016.

2. Jafari, M.J.; Khajevandi, A.A.; Najarkola, S.A.M.; Yekaninejad, M.S.; Pourhoseingholi Amin, M.; Omidi, L.; Kalantary, S. Association of sick building syndrome with indoor air parameters. Tanaffos 2015, 14, 55. [PubMed]

3. Van Durme, J.; Dewulf, J.; Sysmans, W.; Leys, C.; Van Langenhove, H. Abatement and degradation pathways of toluene in indoor air by positive corona discharge. Chemosphere 2007, 68, 1821-1829. [CrossRef] [PubMed]

4. He, C.; Morawska, L.; Hitchins, J.; Gilbert, D. Contribution from indoor sources to particle number and mass concentrations in residential houses. Atmos. Environ. 2004, 38, 3405-3415. [CrossRef]

5. Brown, N.J. Indoor Air Quality; Cornell Univ ILR Sch: Ithaca, NY, USA, 2019.

6. Goodman, N.B.; Steinemann, A.; Wheeler, A.J.; Paevere, P.J.; Cheng, M.; Brown, S.K. Volatile organic compounds within indoor environments in Australia. Build. Environ. 2017, 122, 116-125. [CrossRef]

7. Meyer, B.; Hermanns, K.; Smith, D.C. Formaldehyde release from urea-formaldehyde bonded wood products. J. Adhes 1985, 17, 297-308. [CrossRef]

8. Mujan, I.; Anđelković, A.S.; Munćan, V.; Kljajić, M.; Ružić, D. Influence of indoor environmental quality on human health and productivity-A review. J. Clean. Prod. 2019, 217, 646-657. [CrossRef]

9. World Health Organization. Public Health, Environmental and Social Determinants of Health (PHE); World Heal Organ: Geneva, Switzerland, 2017.

10. Seltzer, J.M. Building-related illnesses. J. Allergy Clin. Immunol. 1994, 94, 351-361. [CrossRef]

11. Menzies, D.; Bourbeau, J. Building-related illnesses. N. Engl. J. Med. 1997, 337, 1524-1531. [CrossRef]

12. Saeki, Y.; Kadonosono, K.; Uchio, E. Clinical and allergological analysis of ocular manifestations of sick building syndrome. Clin. Ophthalmol. 2017, 11, 517-522. [CrossRef]

13. Horvath, E.P. Building-related illness and sick building syndrome: From the specific to the vague. Clevel. Clin. J. Med. 1997, 64, 303-309. [CrossRef]

14. SAIF. Indoor Air Quality Investigations. SS-436 2018. Available online: https://www.saif.com/ Documents/SafetyandHealth/IndoorAirQuality/SS436_indoor_air_quality_investigation.pdf (accessed on 8 November 2018).

15. Herr, C.; Otterbach, I.; Nowak, D.; Hornberg, C.; Eikmann, T.; Wiesmüller, G.A. Clinical environmental medicine. Klin. Dtsch Arztebl.Umweltmed. 2008, 105, 523-531. [CrossRef] [PubMed]

16. EPA. Report to Congress on Indoor Air Quality, Volume II: Assessment and Control of Indoor Air Pollution; EPA: Washington, DC, USA, 1989.

17. Nezis, I.; Biskos, G.; Eleftheriadis, K.; Kalantzi, O.I. Particulate matter and health effects in offices-A review. Build. Environ. 2019, 156, 62-73. [CrossRef]

18. Fisk, W.J. Health and productivity gains from better indoor environments and their relationship with building energy efficiency. Annu. Rev. Energy Environ. 2000, 25, 537-566. [CrossRef]

19. Mendell, M.J.; Fisk, W.J.; Kreiss, K.; Levin, H.; Alexander, D.; Cain, W.S.; Rexroat, L.P. Improving the health of workers in indoor environments: Priority research needs for a National Occupational Research Agenda. Am. J. Public Health 2002, 92, 1430-1440. [CrossRef] [PubMed]

20. Kibert, C.J. Sustainable Construction: Green Building Design and Delivery; John Wiley \& Sons: Hoboken, NJ, USA, 2016.

21. De Robles, D.; Kramer, S.W. Improving Indoor Air Quality through the Use of Ultraviolet Technology in Commercial Buildings. Procedia Eng. 2017, 196, 888-894. [CrossRef] 
22. Amin, N.D.M.; Akasah, Z.A.; Razzaly, W. Architectural evaluation of thermal comfort: Sick building syndrome symptoms in engineering education laboratories. Procedia Soc. Behav. Sci. 2015, 204, 19-28. [CrossRef]

23. Magnavita, N. Work-related symptoms in indoor environments: A puzzling problem for the occupational physician. Int. Arch. Occup. Environ. Health 2015, 88, 185-196. [CrossRef]

24. Norbäck, D.; Hashim, J.H.; Markowicz, P.; Cai, G.-H.; Hashim, Z.; Ali, F.; Larsson, L. Endotoxin, ergosterol, muramic acid and fungal DNA in dust from schools in Johor Bahru, Malaysia-Associations with rhinitis and sick building syndrome (SBS) in junior high school students. Sci. Total Environ. 2016, 545, 95-103. [CrossRef]

25. Nordström, K.; Norbäck, D.; Akselsson, R. Influence of indoor air quality and personal factors on the sick building syndrome (SBS) in Swedish geriatric hospitals. Occup. Environ. Med. 1995, 52, 170-176. [CrossRef]

26. Lahtinen, M.; Huuhtanen, P.; Reijula, K. Sick Building Syndrome and Psychosocial Factors-A Literature Review. Indoor Air 1998, 8, 71-80. [CrossRef]

27. Chirico, F.; Ferrari, G.; Taino, G.; Oddone, E.; Giorgi, I.; Imbriani, M. Prevalence and risk factors for sick building syndrome among Italian correctional officers: A pilot study. J. Health Soc. Sci. 2017, 2, 31-46.

28. Ghaffarianhoseini, A.; AlWaer, H.; Omrany, H.; Ghaffarianhoseini, A.; Alalouch, C.; Clements-Croome, D.; Tookey, J. Sick building syndrome: Are we doing enough. Archit Sci. Rev. 2018, 61, 99-121. [CrossRef]

29. ASHRAE. ; ANSI. Standard 55-2017, Thermal Environmental Comfort Conditions for Human Occupancy; ASHRAE: Atlanta, GA, USA, 2013.

30. Goss, K.U. Effects of temperature and relative humidity on the sorption of organic vapors on quartz sand. Environ. Sci. Technol. 1992, 26, 2287-2294. [CrossRef]

31. Pegas, P.N.; Alves, C.A.; Evtyugina, M.G.; Nunes, T.; Cerqueira, M.; Franchi, M.; Pio, C.A.; Almeida, S.M.; Freitas, M.C. Indoor air quality in elementary schools of Lisbon in spring. Environ. Geochem. Health 2011, 33, 455-468. [CrossRef]

32. Smith, K.R. National burden of disease in India from indoor air pollution. Proc. Natl. Acad. Sci. USA 2000, 97, 13286-13293. [CrossRef] [PubMed]

33. Bael, D.; Sample, J. Life and Breath-How Air Pollution Affects Public Health in the Twin Cities; Minnesota Pollut Control Agency (MPCA) \& Minnesota Department Health: St Paul, MN, USA, 2015; pp. 1-50.

34. CDC. Centers for Disease Control and Prevention, Populations at Risk from Particulate Air Pollution-United States; MMWR, Morbidity and Mortality Weekly Report. n.d.; CDC: Atlanta, GA, USA, 1992.

35. Mendes, A.; Pereira, C.; Mendes, D.; Aguiar, L.; Neves, P.; Silva, S.; Batterman, S.; Teixeira, P.S. Indoor air quality and thermal comfort-Results of a pilot study in elderly care centers in Portugal. J. Toxicol. Environ. Health A 2013, 76, 333-344. [CrossRef]

36. Simoni, M.; Jaakkola, M.S.; Carrozzi, L.; Baldacci, S.; Di Pede, F.; Viegi, G. Indoor air pollution and respiratory health in the elderly. Eur. Respir. J. 2003, 21, 15-20. [CrossRef]

37. Mishra, V. Effect of indoor air pollution from biomass combustion prevalence of asthma in the elderly. Environ. Health Perspect 2003, 111, 71-78. [CrossRef]

38. Franklin, P.J. Indoor air quality and respiratory health of children. Paediatr. Respir. Rev. 2007, 8, $281-286$. [CrossRef]

39. Smith, K.R.; Samet, J.M.; Romieu, I.; Bruce, N. Indoor air pollution in developing countries and acute lower respiratory infections in children. Thorax 2000, 55, 518-532. [CrossRef]

40. World Health Organization. Effects of Air Pollution Children's Health and Development: A Review of the Evidence; WHO Regional Office for Europe: Copenhagen, Denmark, 2005.

41. Flynn, E.; Matz, P.; Woolf, A.; Wright, R. Indoor Air Pollutants Affecting Child Health. A Project of the American College of Medical Toxicology. 2000, pp. 1-201. Available online: http://www.sygdoms.com/pdf/ 23.pdf (accessed on 12 November 2018).

42. Simoni, M.; Baldacci, S.; Maio, S.; Cerrai, S.; Sarno, G.; Viegi, G. Adverse effects of outdoor pollution in the elderly. J. Thorac. Dis. 2015, 7, 34.

43. NSW Government. Who Is Affected by Air Pollution? n.d. Available online: http://www.health.nsw.gov.au/ environment/air/Pages/who-is-affected.aspx (accessed on 12 November 2018).

44. Mendy, A.; Wilkerson, J.; Salo, P.M.; Weir, C.H.; Feinstein, L.; Zeldin, D.C.; Thorne, P.S. Synergistic association of house endotoxin exposure and ambient air pollution with asthma outcomes. Am. J. Respir. Crit. Care Med. 2019, 200, 712-720. [CrossRef] [PubMed] 
45. Abramson, M.J.; Guo, Y. Indoor Endotoxin Exposure and Ambient Air Pollutants Interact on Asthma Outcomes. Am. J. Respir. Crit. Care Med. 2019, 200, 652-654. [CrossRef] [PubMed]

46. Kanchongkittiphon, W.; Mendell, M.J.; Gaffin, J.M.; Wang, G.; Phipatanakul, W. Indoor environmental exposures and exacerbation of asthma: An update to the 2000 review by the Institute of Medicine. Environ. Health Perspect. 2014, 123, 6-20. [CrossRef] [PubMed]

47. State of the AIR; American Lung Association (ALA). National Headquarters, American Lung Association, State of the Air, and Fighting for Air are Registered Trademarks of the American Lung Association; State of the AIR: Chicago, IL, USA, 2020; p. 60601.

48. Shao, M.; Zhang, Y.; Zeng, L.; Tang, X.; Zhang, J.; Zhong, L.; Wang, B. Ground-level ozone in the Pearl River Delta and the roles of VOC and NOx in its production. J. Environ. Manag. 2009, 90, 512-518. [CrossRef] [PubMed]

49. Uysal, N.; Schapira, R.M. Effects of ozone on lung function and lung diseases. Curr. Opin. Pulm. Med. 2003, 9, 144-150. [CrossRef] [PubMed]

50. Care process Model (CPM). Outdoor Air Quality and Health. Intermountain LiVe Well and the Office of the Sustainability. Intermt LiVe Well Off Sustain 2015. Available online: https://intermountainhealthcare.org/ext/ Dcmnt?ncid=527926681 (accessed on 17 November 2019).

51. Bernstein, J.A.; Alexis, N.; Bacchus, H.; Bernstein, I.L.; Fritz, P.; Horner, E.; Li, N.; Mason, S.; Nel, A.; Oullette, J.; et al. The health effects of nonindustrial indoor air pollution. J. Allergy Clin. Immunol. 2008, 121, 585-591. [CrossRef] [PubMed]

52. Seppänen, O.A.; Fisk, W.J.; Mendell, M.J. Association of ventilation rates and $\mathrm{CO}_{2}$ concentrations with health andother responses in commercial and institutional buildings. Indoor Air 1999, 9, 226-252. [CrossRef]

53. Erdmann, C.A.; Steiner, K.C.; Apte, M.G. Indoor Carbon Dioxide Concentrations and Sick Building Syndrome Symptoms in the BASE Study Revisited: Analyses of the 100 Building Dataset; Lawrence Berkeley National Lab. (LBNL): Berkeley, CA, USA, 2002.

54. Arndt, R.L.; Carmichael, G.R.; Streets, D.G.; Bhatti, N. Sulfur dioxide emissions and sectorial contributions to sulfur deposition in Asia. Atmos. Environ. 1997, 31, 1553-1572. [CrossRef]

55. EPA, U. Sulfur Dioxide $\left(\mathrm{SO}_{2}\right)$ Pollution. United States Environ Prot Agency 2019. Available online: https://www.epa.gov/so2-pollution/sulfur-dioxide-basics\#whatisso2 (accessed on 8 May 2019).

56. Spengler, J.D.; Ferris, B.G.; Dockery, D.W.; Speizer, F.E. Sulfur Dioxide and Nitrogen Dioxide Levels Inside and Outside Homes and the Implications on Health Effects Research. Environ. Sci. Technol. 1979, 13, 1276-1280. [CrossRef]

57. Siwarom, S.; Puranitee, P.; Plitponkarnpim, A.; Manuyakorn, W.; Sinitkul, R.; Vallipakorn, S.A.O. Association of indoor air quality and preschool children's respiratory symptoms. Asian Pac. J. Allergy Immunol. 2017, 35, 119-126. [CrossRef]

58. Ielpo, P.; Mangia, C.; Marra, G.P.; Comite, V.; Rizza, U.; Uricchio, V.F.; Fermo, P. Outdoor spatial distribution and indoor levels of $\mathrm{NO}_{2}$ and $\mathrm{SO}_{2}$ in a high environmental risk site of the South Italy. Sci. Total Environ. 2019, 648, 787-797. [CrossRef]

59. Shehu, M.S.; Umaru, I.; Tukura, B.W. Health Impact Analysis of Some Outdoor Atmospheric. Am. J. Public Health Res. 2019, 7, 1-8. [CrossRef]

60. Dunlea, E.J.; Herndon, S.C.; Nelson, D.D.; Volkamer, R.M.; Martini, F.S.; Sheehy, P.M.; Zahniser, M.S.; Shorter, J.H.; Wormhoudt, J.C.; Lamb, B.K.; et al. Evaluation of nitrogen dioxide chemiluminescence monitors in a polluted urban environment. Atmos. Chem. Phys. 2007, 7, 2691-2704. [CrossRef]

61. Yin, J.; Harrison, R.M. Pragmatic mass closure study for $\mathrm{PM}_{1.0}, \mathrm{PM}_{2.5}$ and $\mathrm{PM}_{10}$ at roadside, urban background and rural sites. Atmos. Environ. 2008, 42, 980-988. [CrossRef]

62. Chock, D.P. An advection-diffusion model for pollutant dispersion near roadways. J. Appl. Meteorol. 1978, 17, 976-989. [CrossRef]

63. Wagner, J.G.; Kamal, A.S.; Morishita, M.; Dvonch, J.T.; Harkema, J.R.; Rohr, A.C. PM 2.5 -induced cardiovascular dysregulation in rats is associated with elemental carbon and temperature-resolved carbon subfractions. Part Fibre Toxicol. 2014, 11, 25. [CrossRef]

64. Ehrlich, C.; Noll, G.; Kalkoff, W.-D.; Baumbach, G.; Dreiseidler, A. PM10, $\mathrm{PM}_{2.5}$ and $\mathrm{PM}_{1.0}$-Emissions from industrial plants-Results from measurement programmes in Germany. Atmos. Environ. 2007, 41, 6236-6254. [CrossRef] 
65. Lelieveld, J.; Evans, J.S.; Fnais, M.; Giannadaki, D.; Pozzer, A. The contribution of outdoor air pollution sources to premature mortality on a global scale. Nature 2015, 525, 367. [CrossRef]

66. Ishizaka, T.D.; Kawashima, A.; Hishida, N.; Hamada, N. Measurement of total volatile organic compound (TVOC) in indoor air using passive solvent extraction method. Air. Qual. Atmos. Heal 2019, 12, 173-187. [CrossRef]

67. EPA. Volatile Organic Compounds' Impact on Indoor Air Quality. United States Environ Prot Agency 2017. Available online: https://www.epa.gov/indoor-air-quality-iaq/volatile-organic-compounds-impact-indoorair-quality\#intro (accessed on 4 February 2018).

68. Salthammer, T. Very volatile organic compounds: An understudied class of indoor air pollutants. Indoor Air 2016, 26, 25-38. [CrossRef] [PubMed]

69. Rehwagen, M.; Schlink, U.; Herbarth, O. Seasonal cycle of VOCs in apartments. Indoor Air 2003, 13, $283-291$. [CrossRef] [PubMed]

70. Ohura, T.; Amagai, T.; Shen, X.; Li, S.; Zhang, P.; Zhu, L. Comparative study on indoor air quality in Japan and China: Characteristics of residential indoor and outdoor VOCs. Atmos. Environ. 2009, 43, 6352-6359. [CrossRef]

71. Solomon, S.J.; Schade, G.W.; Kuttippurath, J.; Ladstätter-Weissenmayer, A.; Burrows, J.P. VOC concentrations in an indoor workplace environment of a university building. Indoor Built. Environ. 2008, 17, 260-268. [CrossRef]

72. de Blas, M.; Navazo, M.; Alonso, L.; Durana, N.; Gomez, M.C.; Iza, J. Simultaneous indoor and outdoor on-line hourly monitoring of atmospheric volatile organic compounds in an urban building. The role of inside and outside sources. Sci. Total Environ. 2012, 426, 327-335. [CrossRef]

73. EPA. Initial List of Hazardous Air Pollutants with Modifications. US Environ Prot Agency 2017. Available online: https://www.epa.gov/haps/initial-list-hazardous-air-pollutants-modifications\#mods (accessed on 1 April 2020).

74. ASHRAE, A. ASHRAE Standard 62.1-2016, Ventilation for Acceptable Indoor Air Quality; American Society of Heating, Refrigerating, and Air-Conditioning Engineers: Atlanta, GA, USA, 2016.

75. Chin, J.Y.; Godwin, C.; Parker, E.; Robins, T.; Lewis, T.; Harbin, P.; Batterman, S. Levels and sources of volatile organic compounds in homes of children with asthma. Indoor Air 2014, 24, 403-415. [CrossRef]

76. Civan, M.Y.; Elbir, T.; Seyfioglu, R.; Kuntasal, Ö.O.; Bayram, A.; Doğan, G.; Yurdakul, S.; Andiç, Ö.; Müezzinoğlu, A.; Sofuoglu, S.C.; et al. Spatial and temporal variations in atmospheric VOCs, $\mathrm{NO}_{2}, \mathrm{SO}_{2}$, and $\mathrm{O}_{3}$ concentrations at a heavily industrialized region in Western Turkey, and assessment of the carcinogenic risk levels of benzene. Atmos. Environ. 2015, 103, 102-113. [CrossRef]

77. Tsai, W.-T. Toxic Volatile Organic Compounds (VOCs) in the Atmospheric Environment: Regulatory Aspects and Monitoring in Japan and Korea. Environments 2016, 3, 23. [CrossRef]

78. Andersson, K. TVOC and health in non-industrial indoor environments report from a nordic scientific consensus meeting at I̊ngholmen in Stockholm, 1996. Indoor Air 1997, 7, 78-91. [CrossRef]

79. Yang, J.; Seo, J.H.; Jeong, N.N.; Sohn, J.R. Effects of Legal Regulation Indoor Air Quality in Facilities for Sensitive Populations-A Field Study in Seoul, Korea. Environ. Manag. 2019, 64, 344-352. [CrossRef]

80. Hsu, C.Y.; Chiang, H.C.; Shie, R.H.; Ku, C.H.; Lin, T.Y.; Chen, M.J.; Chen, N.T.; Chen, Y.C. Ambient VOCs in residential areas near a large-scale petrochemical complex: Spatiotemporal variation, source apportionment and health risk. Environ. Pollut. 2018, 240, 95-104. [CrossRef]

81. Fang, L.; Clausen, G.; Fanger, P.O. Impact of temperature and humidity on the perception of indoor air quality. Indoor Air 1998, 8, 80-90. [CrossRef]

82. Berglund, L.G. Perceived air quality and the thermal environment, The Human Equation: Health and Comfort. In Proceedings of the ASHRAE/SOEH Conferece IAQ'89, Atlanta, GA, USA, 21-25 April 1989; pp. 93-99.

83. Morawska, L.; Thai, P.K.; Liu, X.; Asumadu-Sakyi, A.; Ayoko, G.; Bartonova, A.; Bedini, A.; Chai, F.; Christensen, B.; Dunbabin, N.; et al. Applications of low-cost sensing technologies for air quality monitoring and exposure assessment: How far have they gone? Environ. Int. 2018, 116, 286-299. [CrossRef] [PubMed]

84. Munir, S.; Mayfield, M.; Coca, D.; Jubb, S.A.; Osammor, O. Analysing the performance of low-cost air quality sensors, their drivers, relative benefits and calibration in cities-A case study in Sheffield. Environ. Monit. Assess 2019, 191, 94. [CrossRef] 
85. Ahangar, F.E.; Freedman, F.R.; Venkatram, A. Using low-cost air quality sensor networks to improve the spatial and temporal resolution of concentration maps. Int. J. Environ. Res. Public Health 2019, 16, 1252. [CrossRef] [PubMed]

86. Yi, W.Y.; Lo, K.M.; Mak, T.; Leung, K.S.; Leung, Y.; Meng, M.L. A survey of wireless sensor network based air pollution monitoring systems. Sensors 2015, 15, 9859. [CrossRef]

87. Thompson, J.E. Crowd-sourced air quality studies: A review of the literature \& portable sensors. Trends. Environ. Anal. Chem. 2016, 11, 23-34. [CrossRef]

88. Schneider, P.; Castell, N.; Vogt, M.; Dauge, F.R.; Lahoz, W.A.; Bartonova, A. Mapping urban air quality in near real-time using observations from low-cost sensors and model information. Environ. Int. 2017, 106, 234-247. [CrossRef]

89. Chatzidiakou, L.; Krause, A.; Popoola, O.; Di Antonio, A.; Kellaway, M.; Han, Y.; Squires, F.A.; Wang, T.; Zhang, H.; Wang, Q. Characterising low-cost sensors in highly portable platforms to quantify personal exposure in diverse environments. Atmos. Meas. Tech. 2019, 12, 4643-4657. [CrossRef]

90. Collier-Oxandale, A.; Feenstra, B.; Papapostolou, V.; Zhang, H.; Kuang, M.; Der Boghossian, B.; Polidori, A. Field and laboratory performance evaluations of 28 gas-phase air quality sensors by the AQ-SPEC program. Atmos. Environ. 2020, 220, 117092. [CrossRef]

91. Mukherjee, A.; Stanton, L.G.; Graham, A.R.; Roberts, P.T. Assessing the utility of low-cost particulate matter sensors over a 12-week period in the Cuyama valley of California. Sensors (Switzerland) 2017, 17, 1805. [CrossRef] [PubMed]

92. Piedrahita, R.; Xiang, Y.; Masson, N.; Ortega, J.; Collier, A.; Jiang, Y.; Li, K.; Dick, R.P.; Lv, Q.; Hannigan, M.; et al. The next generation of low-cost personal air quality sensors for quantitative exposure monitoring. Atmos. Meas. Tech. 2014, 7, 3325-3336. [CrossRef]

93. SR-G04. BW Ozone Sensor 0-1ppm (SR-G04), Gas Sensor n.d. Available online: https://www.gas-sensing. com/bw-ozone-sensor-sr-g04.html (accessed on 25 July 2019).

94. UHoo-O3. uHoo Sensor Ozone specifications. UHoo Air n.d. Available online: https://uhooair.com/product2/ (accessed on 28 July 2019).

95. ME3-O3. Electrochemical Sensor, Zhengzhou Winsen Electronics Technology Co., Ltd., 2017. 2017. Available online: https://www.winsen-sensor.com/d/files/PDF/ElectrochemicalGasSensor/4-seriesElectrochemical/ ME3-O30-20ppm(Ver1.2)Manual.pdf (accessed on 26 July 2019).

96. DGS-O3. DGS-O3 986-042, Digital Gas Sensor- Ozone, SPEC Sensors n.d. Available online: https://www. spec-sensors.com/wp-content/uploads/2017/01/DGS-O3-968-042_9-6-17.pdf (accessed on 25 July 2019).

97. ULPSMO3. Ultra-Low Power Analog Sensor Module for Ozone, ULPSM-O3968-005, Digital Gas Sensor-Ozone; SPEC Sensors n.d. SPRC-Sensor: Newark, CA, USA, 2017.

98. ZE25-O3. Electrochemical Ozone Detection Module ZE25-O3; Zhengzhou Winsen Electron Technol Co., Ltd.: Zhengzhou, China, 2018.

99. MQ131. Semiconductor Sensor for Ozone. Zhengzhou Winsen Electron Technol Co, Ltd. 2017. Available online: https://www.winsensensor.com/d/files/PDF/SemiconductorGasSensor/mq131(high-concentration) -ver1_4-manual.pdf (accessed on 26 July 2019).

100. MiCS-2610. A1A-MiCS-2610 Version 2, e2v technologies (uk) limited July 2008, n.d. Available online: https://sgx.cdistore.com/datasheets/sgx/mics-2610.pdf (accessed on 26 July 2019).

101. UHoo. uHoo Air Quality Sensor Specifications:, n.d. Available online: https://reviewsofairpurifiers.com/ uhoo-air-quality-sensor-review/ (accessed on 28 July 2019).

102. COB4. COB4, Carbon Mono CO-B4, Carbon Monoxide Sensor, Alphasense Ltd. n.d. Available online: http://www.alphasense.com/WEB1213/wp-content/uploads/2019/09/CO-B4.pdf (accessed on 26 July 2019).

103. COB4PRO. COB4, Smart Gases PRO Technical Guide, Libelium Comunicaciones Distribuidas, S.L. Document version: v7.6—02/2019 n.d. Available online: http://www.libelium.com/downloads/documentation/gases_ sensor_board_pro.pdf (accessed on 26 July 2019).

104. MNS9. Monnit Wireless Carbon Monoxide (CO) Gas Sensor-Commercial AA Battery. Powered n.d. Available online: https://www.monnit.com/Product/MNS-9-W1-GS-C1 (accessed on 26 July 2019).

105. 968-034 D-C. DigitalGas Sensor-Carbon Monoxide n.d. Available online: https://www.digikey.com/en/ products/detail/spec-sensors-11c/968-034/6676880 (accessed on 26 July 2019). 
106. MiCS-4514. The MiCS-4514, 0278 rev 15. A Compact MOS Sensor with Two Fully Independent Sensing Elements on e Package. n.d. Available online: https://www.sgxsensortech.com/content/uploads/2014/08/ 0278_Datasheet-MiCS-4514.pdf (accessed on 28 July 2019).

107. TGS5342. TGS 5342, Sensor for the Detection of Carbon Monoxide, Figaro, n.d. Available online: https: //cdn.sparkfun.com/assets/8/4/3/e/f/52a8c005757b7f292e8b456c.pdf (accessed on 29 July 2019).

108. TGS2442. TGS 2442-For the detection of Carbon Monoxide, product information. FIGARO USA INC n.d. Available online: https://cdn.sos.sk/productdata/af/2e/9901fb15/tgs-2442.pdf (accessed on 26 July 2019).

109. HS-134. Carbon Monoxide sensor element, Sencera n.d. Available online: https://www.tme.eu/Document/ b4e5250ef234a352fb2b89cc5de7675b/HS-134.pdf (accessed on 28 July 2019).

110. MiCS-5524. The MiCS-5524 is a Compact MOS Sensor, SGX Sensortech n.d. Available online: https: //www.mouser.com/datasheet/2/18/1084_Datasheet-MiCS-5524-rev-8-1144838.pdf (accessed on 28 July 2019).

111. TGS5042. Figaro, Product Datasheet rev04,n.d. Available online: https://www.figaro.co.jp/en/product/docs/ tgs5042_productinfomation\%28en\%29_rev04.pdf (accessed on 28 July 2019).

112. MQ -7. CO Sensor, HANWEI ELECTRONICS CO., LTD. n.d. Available online: https://www.sparkfun.com/ da.asheets/Sensors/Biometric/MQ-7.pdf (accessed on 26 July 2019).

113. GC0024. ExplorIR®-M 20\% $\mathrm{CO}_{2}$ Sensor, Product Information, n.d. Available online: https://www.co2meter. com/products/minir-co2-sensor (accessed on 30 July 2019).

114. $\mathrm{CO}_{2}$. AWAIR $\mathrm{CO}_{2}$, Carbon Dioxide $\left(\mathrm{CO}_{2}\right)$ Sensor, Product Information n.d. Available online: https: //images-na.ssl-images-amazon.com/images/I/B1-qbtPfPaS.pdf (accessed on 30 July 2019).

115. B-530. ELT Sensor Data Sheet n.d. Available online: http://eltsensor.co.kr/2012/eng/product/carbon-dioxidesensor-module.html (accessed on 30 July 2019).

116. Moreno-Rangel, A.; Sharpe, T.; Musau, F.; McGill, G. Field evaluation of a low-cost indoor air quality monitor to quantify exposure to pollutants in residential environments. J. Sensors Sens. Syst. 2018, 7, 373-388. [CrossRef]

117. 8096-AP. 8096-AP, $\mathrm{CO}_{2}$, Specification, Air Mentor pro n.d. Available online: https://air-mentor.eu/product/ air_mentor_8096ap.html\#specification (accessed on 30 July 2019).

118. Yocto-VOC-V3. USB Environmental Sensors. specifications n.d. Available online: http://www.yoctopuce. com/EN/products/usb-environmental-sensors/yocto-voc-v3 (accessed on 31 July 2019).

119. NWS01-EU.; Netatmo, Netatmo Weather Station NWS01. Version 1, May 2012 n.d. Available online: https://images-eu.ssl-images-amazon.com/images/I/A1RvwZ80UpS.pdf (accessed on 28 July 2019).

120. CozIR®-LP2. CozIR®-LP2, Sensor Datasheet n.d. Available online: https://www.gassensing.co.uk/wpcontent/uploads/2019/06/CozIR-LP2-Datasheet.pdf (accessed on 30 July 2019).

121. K-30. K-30, CO2Meter n.d. Available online: https://img.ozdisan.com/ETicaret_Dosya/456729_1584920.PDF (accessed on 30 July 2019).

122. D-400. D-400. ELT Corp. Sensor Data Sheet, n.d. Available online: http://eltsensor.co.kr/2016/file/oem_ modules/DS_D-400_ver\%201.0_eng_new.pdf (accessed on 30 July 2019).

123. GC-0015. ExplorIR ${ }^{\circledR}-\mathrm{W} 5 \% \mathrm{CO}_{2}$. Sensor. Available online: https://gaslab.com/products/co2-sensor-gssexplorir-w-5-percent (accessed on 30 July 2019).

124. T-110 - ELT SENSOR. Datasheet. Available online: https://gasdetect.com/wp-content/uploads/2014/08/DS_T110_Rev1.2.pdf (accessed on 30 July 2019).

125. MT-100. MT-100. ELT Sensor Data Sheet, n.d. Available online: https://www.sensorinstock.it/en/8_eltsensor? $\mathrm{p}=2$ (accessed on 30 July 2019).

126. S-300. S-300. ELT Sensor Data Sheet n.d. Available online: https://www.tme.eu/Document/ f2b0a5bcaca9d92f234559ea927d4ca1/DS_S-300-3V_ver1.110.pdf (accessed on 30 July 2019).

127. T6713. T6713, Telaire, Carbon Dioxide $\left(\mathrm{CO}_{2}\right)$ Sensor, Product Information, n.d. Available online: $\quad$ https://www.digikey.com/product-detail/en/amphenol-advanced-sensors/T6713/235-1373ND/5027891\&?gclid=CjwKCAiAsoviBRAoEiwATm8OYOt0ysnaMiBDpWveW3Lm_czWRwsaJiWMB8rIRyiE35h7Yw2SXU0kBoCS1AQAvD_BwE (accessed on 30 July 2019).

128. T6615. T6615, Sensor Product Datasheet n.d. Available online: https://www.amphenol-sensors.com/en/ telaire/co2/525-co2-sensor-modules/319-t6615 (accessed on 30 July 2019).

129. MG-811. $\mathrm{CO}_{2}$ Sensor Module, Carbon Dioxide $\left(\mathrm{CO}_{2}\right)$ Sensor, Product Information n.d. Available online: https://sandboxelectronics.com/?cat=44 (accessed on 30 July 2019). 
130. 4161, T. TGS 4161, Sensor for the Detection of Carbon Dioxide, Figaro, Product Information n.d. Available online: https://cdn.sos.sk/productdata/62/d9/f2bb36a6/tgs-4161.pdf (accessed on 30 July 2019).

131. MH-Z16. Intelligent Infrared Gas Module, Winsen, Zhengzhou Winsen Electronic Technology CO., LTD. Product Information, n.d. Available online: https://www.compel.ru/pdf-items/winsen/pn/mh-z16-ndir-co2sensor/d12adaf2dfb2f751e33928845c54ef43 (accessed on 30 July 2019).

132. MH-Z19. MH-Z19, Intelligent Infrared Gas Module, Winsen, Zhengzhou Winsen Electronic Technology CO., LTD. Product Information n.d. Available online: https://www.circuits.dk/testing-mh-z19-ndir-co2-sensormodule/ (accessed on 30 July 2019).

133. $\mathrm{SO}_{2}$-B4. Sulfur Dioxide Sensor, Alphasense, Technical Specification. 4-Electrode n.d. Available online: https://pdf.directindustry.com/pdf/alphasense/so2-b4/16860-592343.html (accessed on 28 July 2019).

134. ME4-SO $\mathrm{SO}_{2}$ Sulfur Dioxide Gas Sensor, Winsen, Datasheet, n.d. Available online: https: //www.winsen-sensor.com/d/files/PDF/ElectrochemicalGasSensor/7-seriesElectrochemical/ME4-SO2020ppm(Ver1.2)---Manual.pdf (accessed on 28 July 2019).

135. 986-038. DGS-SO2 986-042, Digital Gas Sensor- Ozone, SPEC Sensors, Aug 2017, n.d. Available online: https: //www.spec-sensors.com/wp-content/uploads/2017/01/DGS-SO2-968-038.pdf (accessed on 25 July 2019).

136. EC-4SO $\mathrm{SO}_{2}-2000$. Sulfur Dioxide Electrochemical Sensor EC-4SO $2-2000$, Product Details n.d. Available online: https:/www.scienoc-chem.com/gas-sensors-and-detectors/electrochemical-gas-sensor/ sulfur-dioxide-electrochemical-sensor-ec-4so2.html (accessed on 25 July 2019).

137. MQ-136. GAS SENSOR, Technical Data, n.d. Available online: http://www.sensorica.ru/pdf/MQ-136.pdf (accessed on 25 July 2019).

138. FECS43-20. FECS43-20, FIGARO, FECS43-20-For the Detection of Sulfur Dioxide, Tentative Product Information n.d. Available online: https://www.figaro.co.jp/en/product/docs/fecs43-20_product\% 20infomation(en)_rev01.pdf (accessed on 25 July 2019).

139. 986-043. DGS-NO2 986-042, Digital Gas Sensor- Ozone, SPEC sensors, Aug 2017 n.d. Available online: https://media.digikey.com/pdf/DataSheets/SPECSensorsPDFs/968-043_9-6-17.pdf (accessed on 25 July 2019).

140. Mics6814. SGXtech, Datasheet n.d. Available online: https://sgx.cdistore.com/datasheets/sgx/1143_ datasheetmics-6814rev8.pdf (accessed on 31 July 2019).

141. MiCS-2714. The MiCS-2714, NO2, a Compact MOS Sensor with Two Fully Independent Sensing Elements on e Package. Data Sheet, n.d. Available online: https://www.sgxsensortech.com/content/uploads/2014/08/1107_ Datasheet-MiCS-2714.pdf (accessed on 29 July 2019).

142. NO2-B4. NO2-B4, Sulfur Dioxide Sensor, Alphasense, Technical Specification. 4-Electrode. n.d. Available online: https://pdf.directindustry.com/pdf/alphasense/no2-b4/16860-592349.html (accessed on 29 July 2019).

143. DC1100Pro. Dylos, Technical Specification n.d. Available online: https://www.sylvane.com/laser-particlecounter-pro.html (accessed on 30 July 2019).

144. OPC-N2. PM Sensor, Alphasense User Manual, OPC-N2 Optical Particle Counter, Alphasense, Technical Specification n.d. Available online: http://stg-uneplive.unep.org/media/aqm_document_v1/BluePrint/ Components/Microcomputerandsensors/B.DustSensorSpecifications/B.1AlphasenseOPCN1/072-0300OPCN2manualissue3.pdf (accessed on 30 July 2019).

145. FBT0002100. FBT0002100-PM 2.5 SENSOR, Foobot (Airboxlab) Specifications, n.d. Available online: https: //foobot.io/foobotspecs.pdf (accessed on 28 July 2019).

146. AW6404. AW6404, Pm Sensor, Awair 2nd, Edition, Technical Specification n.d. Available online: https://www.sylvane.com/media/documents/products/owner_manual_awair_2nd_Edition_.pdf (accessed on 29 July 2019).

147. 8096-AP. PM Sensor, Specification, Air Mentor pro. n.d. Available online: https://air-mentor.eu/media/ catalog/product_download/201706131332nie4aEwweGhu.pdf (accessed on 30 July 2019).

148. PPD42NS S, SPS30. Particulate Matter Sensor, Technical Specification. n.d. Available online: https://media.digikey.com/pdf/DataSheets/SensirionPDFs/Sensirion_SPS30_Particulate_Matter_ Sensor_v0.9_D1.pdf (accessed on 31 July 2019).

149. PMS7003. PMS7003, Particulate Matter Sensor, Digital Universal Particle Concentration Sensor. Plantower, 2016 n.d. Available online: https:/download.kamami.com/p564008-p564008-PMS7003seriesdatamanua_ English_V2.5.pdf (accessed on 31 July 2019). 
150. PMS5003. Particulate Matter Sensor, Digital Universal Particle Concentration Sensor. Plantower 2016. Available online: http://www.aqmd.gov/docs/default-source/aq-spec/resources-page/plantower-pms5003manual_v2-3.pdf (accessed on 31 July 2019).

151. HPMA115S0-XXX. HPMA115S0-XXX, HPM Series, Particulate Matter Sensor, Honeywell n.d. Available online: https://sensing.honeywell.com/honeywell-sensing-particulate-hpm-series-datasheet-32322550 (accessed on 30 July 2019).

152. DN7C3CA006. Datasheet. Digi-Key Part Number, 425-2896-ND.. Particulate Matter Sensor, Technical Specification. n.d. Available online: https://www.digchip.com/datasheets/parts/datasheet/424/DN7C3CA006pdf.php (accessed on 31 July 2019).

153. $\mathrm{PM}_{2.5}$ L. Laser $\mathrm{PM}_{2.5}$ Sensor. Nova Fitness Co., Ltd. n.d. Available online: https://cdn-reichelt.de/documents/ datenblatt/X200/SDS011-DATASHEET.pdf (accessed on 31 July 2019).

154. ppd42ns.shinyei ppd42ns datasheet. Available online: https://files.seeedstudio.com/wiki/Grove_Dust_ Sensor/resource/Grove_-_Dust_sensor.pdf. (accessed on 30 July 2019).

155. TIDA-00378. $\mathrm{PM}_{2.5} / \mathrm{PM}_{10}$ Particle Sensor Analog Front-End for Air Quality Monitoring Design. TI Designs, May 2016, n.d. Available online: http://www.ti.com/lit/ug/tidub65c/tidub65c.pdf (accessed on 31 July 2019).

156. ZMOD4410. ZMOD4410, Gas Sensor Module for TVOC and Indoor Air Quality. specifications, n.d. Available online: https://www.idt.com/document/dst/zmod4410-datasheet (accessed on 28 July 2019).

157. Yocto-VOC-V3. USB Environmental Sensors. User's guide.Datasheet n.d. Available online: http://www. yoctopuce.com/EN/productcategories.php (accessed on 31 July 2019).

158. uThing::VOC ${ }^{\mathrm{TM}}$ - Air-Quality USB sensor dongle. Available online: https://ohmtech.io/products/uthingvoc/. (accessed on 31 July 2019).

159. MiCS-5524. 1084 rev 8, The MiCS-5524 is a Compact MOS Sensor. SGXsensorTech. n.d. Available online: https://sgx.cdistore.com/datasheets/sgx/1084_datasheetmics-5524rev8.pdf (accessed on 28 July 2019).

160. IAQ-100C. iAQ-100C, ASPEC, IAQ_100CPackage110-802, Specifications, n.d. Available online: https://www. spec-sensors.com/wp-content/uploads/2016/02/IAQ_100-C-Package-110-802.pdf (accessed on 28 July 2019).

161. SP3s-AQ2-01. NISSAHA, FIS Gas Sensor, Specifications, n.d. Available online: http://www.fisinc.co.jp/en/ common/pdf/SP3SAQ201E_P.pdf (accessed on 28 July 2019).

162. 2602, T. Tvocs, the detection of Air Contaminants, Figaro, Specifications n.d. Available online: http: //www.figarosensor.com/product/docs/TGS2602-B00\%280615\%29.pdf (accessed on 31 July 2019).

163. MICS-VZ-87. The MiCS-VZ-87 is an integrated sensor board for Indoor Air Quality monitoring. MiCS-VZ-87 Preliminary rev 8, SGXsensorTech. n.d. Available online: https://sgx.cdistore.com/datasheets/sgx/mics-vZ87_rev8.pdf (accessed on 28 July 2019).

164. NAAQS. Primary National Ambient Air Quality Standard (NAAQS) for Sulfur Dioxide n.d. Available online: https://www.epa.gov/so2-pollution/primary-national-ambient-air-quality-standard-naaqs-sulfurdioxide (accessed on 26 July 2019).

165. EPA. NAAQS Table. United States Environ Prot Agency 2016. Available online: https://www.epa.gov/ criteria-air-pollutants/naaqs-table (accessed on 26 July 2019).

166. Green, L.C.; Crouch, E.A.C.; Ames, M.R.; Lash, T.L. What's wrong with the National Ambient Air Quality Standard (NAAQS) for fine particulate matter $\left(\mathrm{PM}_{2.5}\right)$ ? Regul. Toxicol. Pharmacol. 2002, 35, 327-337. [CrossRef] [PubMed]

167. EPA. Air Quality-Cities and Counties. United States Environ Prot Agency 2019. Available online: https://www.epa.gov/air-trends/air-quality-cities-and-counties (accessed on 26 July 2019).

168. Fritz, P.M.; Horner, E. NAAQS PM 2.5 or ISO 14644 As an IAQ Metric? ASHRAE J. N. Y. Occup. Saf. Health Adm. 2017, 59, 84-86.

169. OSHA. Indoor Air Quality in Commercial and Institutional Buildings. Maroon Ebooks; Occupational Safety and Health Administration: Washington, DC, USA, 2015.

170. WHO. Ambient (outdoor) Air Pollution. World Heal Organ 2020. Available online: https://www.who.int/ news-room/fact-sheets/detail/ambient-(outdoor)-air-quality-and-health (accessed on 26 July 2019).

171. WHO. WHO Air Quality Guidelines for Particulate Matter, Ozone, Nitrogen Dioxide and Sulfur Dioxide: Global Update 2005: Summary of Risk Assessment; WHO: Geneva, Switzerland, 2006.

172. ACGIH. TLVs ${ }^{\circledR}$ and BEIs ${ }^{\circledR}$ : Threshold Limit Values for Chemical Substances and Physical Agents and Biological Exposure Indices. In American Conference of Governmental Industrial Hygienists; ACGIH: Cincinnati, OH, USA, 2019. 
173. ANSI Ashrae. Standard AS. 62.1. 2007, Ventilation for Acceptable Indoor Air Quality; ANSI Ashrae: Atlanta, GA, USA, 2007.

174. AQMD. National Ambient Air Quality Standards (NAAQS) and California Ambient Air Quality Standards (CAAQS) Attainment Status for South Coast Air Basin. Calif Air Resour Board 2016. Available online: http://www.aqmd.gov/docs/default-source/clean-air-plans/air-quality-management-plans/2016-airquality-management-plan/final-2016-aqmp/chapter2.pdf (accessed on 28 November 2019).

175. Christopher, M.; Resources, P.A.N.; Vol, C. Indoor Airborne Particulate Matter: Unregulated, but a Major Contributor to Our Everyday Exposure. Nat. Resour. Env't 2017, 32, 8-12.

176. World Health Organization (WHO). WHO Guidelines for Indoor Air Quality: Selected Pollutants; World Health Organization: Geneva, Switzerland, 2010.

177. Krzyzanowski, M.; Cohen, A. Update of WHO air quality guidelines. Air Qual. Atmos. Heal 2008, 1, 7-13. [CrossRef]

178. WHO. WHO Expert Consultation: Available Evidence for the Future Update of the WHO Global Air Quality Guidelines (AQGs); WHO: Geneva, Switzerland, 2016.

179. Ahmed Abdul-Wahab, S.A.; En, S.C.F.; Elkamel, A.; Ahmadi, L.; Yetilmezsoy, K. A review of standards and guidelines set by international bodies for the parameters of indoor air quality. Atmos. Pollut. Res. 2015, 6, 751-767. [CrossRef]

180. WHO. Risk of Bias Assesssment Instrument for Systematic; WHO regional office for Europe: Geneva, Switzerland, 2020.

181. ASHRAE. ASHRAE 62.1 The Standards for Ventilation and Indoor Air Quality. ANSI/ASHRAE 2019. Available online: https://www.ashrae.org/technical-resources/bookstore/standards-62-1-62-2 (accessed on 4 April 2020).

182. Persily, A. Challenges in developing ventilation and indoor air quality standards: The story of ASHRAE Standard 62. Build. Environ. 2015, 91, 61-69. [CrossRef]

183. ANSI/ASHRAE. ANSI/ASHRAE Standard 62.1-2019, Ventilation for Acceptable Indoor Air Quality; American Society of Heating, Refrigerating and Air-Conditioning Engineers: Atlanta, GA, USA, 2019.

184. Epa. Building Air Quality—A Guide for Building Owners and Facility Managers; Epa: Washington, DC, USA, 1991; pp. 1-228.

185. OSHA. Indoor Air Quality. Occup Saf Heal Adm US Dep Labor 2019. Available online: https://www.osha. gov/SLTC/indoorairquality/ (accessed on 4 April 2020).

186. OSHA. Permissible Exposure Limits-Annotated Tables. Occup Saf Heal Adm n.d. Available online: https://www.osha.gov/dsg/annotated-pels/ (accessed on 4 April 2020).

187. ACGIH. TLVßChemical Substances Introduction. Am Conf Gov Ind Hyg 2020. Available online: https: //www.acgih.org/tlv-bei-guidelines/tlv-chemical-substances-introduction (accessed on 6 April 2020).

188. Scarborough, J.; Resources, H.; Jennie, D.; Summary, E. Industrial Hygiene Services 04/05/2019. 2019. Available online: https://incoln.k12.or.us/media/2019/04/Lincoln-County-School-District-489788-IndustrialHygiene-Report.031319.pdf (accessed on 4 April 2020).

189. CARB. California Ambient Air Quality Standards. California Ambient Air Quality Standards (CAAQS). Calif Air Resour Board 2020. Available online: https://ww2.arb.ca.gov/resources/california-ambient-airquality-standards (accessed on 4 April 2020).

190. Burke, W.A.; Ed, D.; Carney, J.W. Final 2016 Air Quality Management Plan. South Coast Air Quality Management District. 2016. Available online: http://www.aqmd.gov/docs/default-source/clean-air-plans/ air-quality-management-plans/2016-air-quality-management-plan/final-2016-aqmp/final2016aqmp.pdf (accessed on 4 April 2020).

191. Stewart, D.R.; Saunders, E.; Perea, R.; Fitzgerald, R.; Campbell, D.E.; Stockwell, W.R. Projected changes in particulate matter concentrations in the South Coast Air Basin due to basin-wide reductions in nitrogen oxides, volatile organic compounds, and ammonia emissions. J. Air Waste Manag. Assoc. 2019, 69, 192-208. [CrossRef]

192. SCAQMD. South Coast Air Quality Mnanagement District Draft Staff Report for 2015 8-Hour Ozone Standard Reasonably Available Control Technology (RACT) Demonstration APRIL 2020; SCAQMD: Diamond Bar, CA, USA, 2020.

193. CARB. Ambient Air Monitoring Key Summaries \& References. Available online: https://ww3.arb.ca.gov/ research/research-results.php (accessed on 4 April 2020). 
194. EPA, U. CFR Parts 50, 51, 52, 53, and 58-National Ambient Air Quality Standards for Particulate Matter: Final Rule.Fed. Regist. 40; 78, 3086-3286. n.d.; EPA: Washington, DC, USA, 2020.

195. Majd, E.; McCormack, M.; Davis, M.; Curriero, F.; Berman, J.; Connolly, F.; Leaf, P.; Rule, A.; Green, T.; Erby, D.C.; et al. Indoor air quality in inner-city schools and its associations with building characteristics and environmental factors. Environ. Res. 2019, 170, 83-91. [CrossRef]

196. Bennett, J.; Davy, P.; Trompetter, B.; Wang, Y.; Pierse, N.; Boulic, M.; Phipps, R.; Howden-Chapman, P. Sources of indoor air pollution at a New Zealand urban primary school; a case study. Atmos Pollut Res. 2019, 10, 435-444. [CrossRef]

197. Nkosi, V.; Wichmann, J.; Voyi, K. Indoor and outdoor PM 10 levels at schools located near mine dumps in Gauteng and North West Provinces, South Africa. BMC Public Health 2017, 17, 42. [CrossRef] [PubMed]

198. Raysoni, A.U.; Stock, T.H.; Sarnat, J.A.; Chavez, M.C.; Sarnat, S.E.; Montoya, T.; Holguin, F.; Li, W.W. Evaluation of VOC concentrations in indoor and outdoor microenvironments at near-road schools. Environ. Pollut. 2017, 231, 681-693. [CrossRef]

199. Kalimeri, K.K.; Saraga, D.E.; Lazaridis, V.D.; Legkas, N.A.; Missia, D.A.; Tolis, E.I.; Bartzis, J.G. Indoor air quality investigation of the school environment and estimated health risks: Two-season measurements in primary schools in Kozani, Greece. Atmos Pollut Res. 2016, 7, 1128-1142. [CrossRef]

200. Madureira, J.; Paciência, I.; Rufo, J.; Severo, M.; Ramos, E.; Barros, H.; de Oliveira Fernandes, E. Source apportionment of $\mathrm{CO}_{2}, \mathrm{PM}_{10}$ and VOCs levels and health risk assessment in naturally ventilated primary schools in Porto, Portugal. Build. Environ. 2016, 96, 198-205. [CrossRef]

201. Madureira, J.; Paciência, I.; Pereira, C.; Teixeira, J.P.; de Fernandes, E.O. Indoor air quality in Portuguese schools: Levels and sources of pollutants. Indoor Air. 2016, 26, 526-537. [CrossRef]

202. Oliveira, M.; Slezakova, K.; Delerue-Matos, C.; Pereira, M.C.; Morais, S. Assessment of air quality in preschool environments (3-5 years old children) with emphasis on elemental composition of $\mathrm{PM}_{10}$ and $\mathrm{PM}_{2.5}$. Environ. Pollut. 2016, 214, 430-439. [CrossRef]

203. Verriele, M.; Schoemaecker, C.; Hanoune, B.; Leclerc, N.; Germain, S.; Gaudion, V.; Locoge, N. The MERMAID study: Indoor and outdoor average pollutant concentrations in 10 low-energy school buildings in France. Indoor Air. 2016, 26, 702-713. [CrossRef]

204. Mainka, A.; Bragoszewska, E.; Kozielska, B.; Pastuszka, J.S.; Zajusz-Zubek, E. Indoor air quality in urban nursery schools in Gliwice, Poland: Analysis of the case study. Atmos Pollut Res. 2015, 6, 1098-1104. [CrossRef]

205. Mainka, A.; Zajusz-Zubek, E.; Kaczmarek, K. PM 10 composition in urban and rural nursery schools in Upper Silesia, Poland: A trace elements analysis. Int. J. Environ. Pollut. 2017, 61, 98-118. [CrossRef]

206. Vassura, I.; Venturini, E.; Bernardi, E.; Passarini, F.; Settimo, G. Assessment of indoor pollutionin a school environment through both passive and continuous samplings. Environ. Eng. Manag. J. 2015, 14, 1761-1770.

207. Sunyer, J.; Esnaola, M.; Alvarez-Pedrerol, M.; Forns, J.; Rivas, I.; López-Vicente, M.; Suades-González, E.; Foraster, M.; Garcia-Esteban, R.; Basagaña, X.; et al. Association between traffic-related air pollution in schools and cognitive development in primary school children: A prospective cohort study. PLoS Med. 2015, 12, e1001792. [CrossRef]

208. Huang, K.; Song, J.; Feng, G.; Chang, Q.; Jiang, B.; Wang, J.; Sun, W.; Li, H.; Wang, J.; Fang, X. Indoor air quality analysis of residential buildings in northeast China based on field measurements and longtime monitoring. Build. Environ. 2018, 144, 171-183. [CrossRef]

209. Zhao, L.; Liu, J.; Ren, J. Impact of various ventilation modes on IAQ and energy consumption in Chinese dwellings: First long-term monitoring study in Tianjin, China. Build. Environ. 2018, 143, 99-106. [CrossRef]

210. Liu, Z.; Cheng, K.; Li, H.; Cao, G.; Wu, D.; Shi, Y. Exploring the potential relationship between indoor air quality and the concentration of airborne culturable fungi: A combined experimental and neural network modeling study. Environ. Sci. Pollut. Res. 2018, 25, 3510-3517. [CrossRef]

211. Quang, T.N.; Hue, N.T.; Thai, P.; Mazaheri, M.; Morawska, L. Exploratory assessment of indoor and outdoor particle number concentrations in Hanoi households. Sci. Total Environ. 2017, 599, 284-290. [CrossRef]

212. Du, L.; Prasauskas, T.; Leivo, V.; Turunen, M.; Pekkonen, M.; Kiviste, M.; Aaltonen, A.; Martuzevicius, D.; Shaughnessy, U. Assessment of indoor environmental quality in existing multi-family buildings in North-East Europe. Environ. Int. 2015, 79, 74-84. [CrossRef] 
213. Meier, R.; Schindler, C.; Eeftens, M.; Aguilera, I.; Ducret-Stich, R.E.; Ineichen, A.; Davey, M.; Phuleria, H.C.; Probst-Hensch, N.; Tsai, M.Y.; et al. Modeling indoor air pollution of outdoor origin in homes of SAPALDIA subjects in Switzerland. Environ. Int. 2015, 82, 85-91. [CrossRef]

214. Kim, J.; Kong, M.; Hong, T.; Jeong, K.; Lee, M. The effects of filters for an intelligent air pollutant control system considering natural ventilation and the occupants. Sci. Total Environ. 2019, 657, 410-419. [CrossRef]

215. Roshan, S.K.; Godini, H.; Nikmanesh, B.; Bakhshi, H.; Charsizadeh, A. Study on the relationship between the concentration and type of fungal bio-aerosols at indoor and outdoor air in the Children's Medical Center, Tehran, Iran. Environ. Monit Assess. 2019, 191, 48. [CrossRef]

216. Tolis, E.I.; Panaras, G.; Douklias, E.; Ouranos, N.; Bartzis, J.G. Air quality measurements in a medium scale athletic hall: Diurnal and I/O ratio analysis. FEB-FRESENIUS Environ. Bull. 2019, 28, 658-664.

217. Hwang, S.H.; Roh, J.; Park, W.M. Evaluation of $\mathrm{PM}_{10}, \mathrm{CO}_{2}$, airborne bacteria, TVOCs, and formaldehyde in facilities for susceptible populations in South Korea. Environ. Pollut. 2018, 242, 700-708. [CrossRef]

218. Deng, G.; Li, Z.; Wang, Z.Z.; Gao, J.; Xu, Z.; Li, J.; Wang, Z. Indoor/outdoor relationship of PM $_{2 .} 5$ concentration in typical buildings with and without air cleaning in Beijing. Indoor Built Environ. 2017, 26, 60-68. [CrossRef]

219. Saraga, D.; Maggos, T.; Sadoun, E.; Fthenou, E.; Hassan, H.; Tsiouri, V.; Karavoltsos, S.; Sakellari, A.; Vasilakos, C.; Kakosimos, K. Chemical characterization of indoor and outdoor particulate matter $\left(\mathrm{PM}_{2.5}\right.$, $\mathrm{PM}_{10}$ ) in Doha, Qatar. Aerosol Air Qual. Res. 2017, 17, 1156-1168. [CrossRef]

220. Loupa, G.; Zarogianni, A.-M.; Karali, D.; Kosmadakis, I.; Rapsomanikis, S. Indoor/outdoor PM 2.5 elemental composition and organic fraction medications, in a Greek hospital. Sci. Total Environ. 2016, 550, 727-735. [CrossRef]

221. He, Q.; Song, Q.; Yan, Y.; Wang, Z.; Guo, L.; Wang, X. Exposure to particle matters and hazardous volatile organic compounds in selected hot spring hotels in Guangdong, China. Atmosphere (Basel) 2016, 7, 54. [CrossRef]

222. Irga, P.J.; Torpy, F.R. Indoor air pollutants in occupational buildings in a sub-tropical climate: Comparison among ventilation types. Build. Environ. 2016, 98, 190-199. [CrossRef]

223. Shang, Y.; Li, B.; Baldwin, A.N.; Ding, Y.; Yu, W.; Cheng, L. Investigation of indoor air quality in shopping malls during summer in Western China using subjective survey and field measurement. Build. Environ. 2016, 108, 1-11. [CrossRef]

224. Hu, T.; Jia, W.; Cao, J.; Huang, R.; Li, H.; Liu, S.; Ma, T.; Zhu, Y. Indoor air quality at five site museums of Yangtze River civilization. Atmos Environ. 2015, 123, 449-454. [CrossRef]

225. Montgomery, J.F.; Storey, S.; Bartlett, K. Comparison of the indoor air quality in an office operating with natural or mechanical ventilation using short-term intensive pollutant monitoring. Indoor Built Environ. 2015, 24, 777-787. [CrossRef]

226. Challoner, A.; Pilla, F.; Gill, L. Prediction of indoor air exposure from outdoor air quality using an artificial neural network model for inner city commercial buildings. Int. J. Environ. Res. Public Health 2015, 12, 15233-15253. [CrossRef]

227. Kwon, S.-B.; Jeong, W.; Park, D.; Kim, K.-T.; Cho, K.H. A multivariate study for characterizing particulate matter $\left(\mathrm{PM}_{10}, \mathrm{PM}_{2.5}\right.$, and $\left.\mathrm{PM}_{1}\right)$ in Seoul metropolitan subway stations, Korea. J. Hazard Mater. 2015, 297, 295-303. [CrossRef]

228. Mejía, J.F.; Choy, S.L.; Mengersen, K.; Morawska, L. Methodology for assessing exposure and impacts of air pollutants in school children: Data collection, analysis and health effects-A literature review. Atmos. Environ. 2011, 45, 813-823. [CrossRef]

229. Yen, Y.; Yang, C.; Mena, K.D.; Cheng, Y.; Chen, P. Cooking/Window Opening and Associated Increases of Indoor PM 2. 5 and NO 2 Concentrations of Children' s Houses in Kaohsiung, Taiwan. Appl. Sci. 2019, 9, 4306. [CrossRef]

230. Johnson, D.L.; Lynch, R.A.; Floyd, E.L.; Wang, J.; Bartels, J.N. Indoor air quality in classrooms: Environmental measures and effective ventilation rate modeling in urban elementary schools. Build. Environ. 2018, 136, 185-197. [CrossRef]

231. Branco, P.T.B.S.; Nunes, R.A.O.; Alvim-Ferraz, M.C.M.; Martins, F.G.; Sousa, S.I.V. Children's exposure to indoor air in urban nurseries-Part II: Gaseous pollutants' assessment. Environ. Res. 2015, 142, 662-670. [CrossRef] 
232. Madureira, J.; Aguiar, L.; Pereira, C.; Mendes, A.; Querido, M.M.; Neves, P.; Teixeira, J.P. Indoor exposure to bioaerosol particles: Levels and implications for inhalation dose rates in schoolchildren. Air Qual. Atmos. Health 2018, 11, 955-964. [CrossRef]

233. Nunes, R.A.O.; Branco, P.T.B.S.; Alvim-Ferraz, M.C.M.; Martins, F.G.; Sousa, S.I.V. Gaseous pollutants on rural and urban nursery schools in Northern Portugal. Environ. Pollut. 2016, 208, 2-15. [CrossRef] [PubMed]

234. Fishbain, B.; Lerner, U.; Castell, N.; Cole-Hunter, T.; Popoola, O.; Broday, D.M.; Iñiguez, T.M.; Nieuwenhuijsen, M.; Jovasevic-Stojanovic, M.; Topalovic, D.; et al. An evaluation tool kit of air quality micro-sensing units. Sci. Total Environ. 2017, 575, 639-648. [CrossRef]

235. Scibor, M. Are we safe inside? Indoor air quality in relation to outdoor concentration of $\mathrm{PM}_{10}$ and $\mathrm{PM}_{2.5}$ and to characteristics of homes. Sustain. Cities Soc. 2019, 48, 101537. [CrossRef]

236. Saraga, D.E.; Volanis, L.; Maggos, T.; Vasilakos, C.; Bairachtari, K.; Helmis, C.G. Workplace personal exposure to respirable PM fraction: A study in sixteen indoor environments. Atmos. Pollut. Res. 2014, 5, 431-437. [CrossRef]

237. De Vito, S.; Piga, M.; Martinotto, L.; Di Francia, G. CO, NO2 and NOx urban pollution monitoring with on-field calibrated electronic nose by automatic bayesian regularization. Sensors Actuators B Chem. 2009, 143, 182-191. [CrossRef]

238. Gvozdić, V.; Kovač-Andrić, E.; Brana, J. Influence of Meteorological Factors $\mathrm{NO}_{2}, \mathrm{SO}_{2}, \mathrm{CO}$ and $\mathrm{PM}_{10}$ on the Concentration of $\mathrm{O} 3$ in the Urban Atmosphere of Eastern Croatia. Environ. Model. Assess. 2011, 16, 491-501. [CrossRef]

239. Chock, D.P.; Winkler, S.L.; Chen, C. A study of the association between daily mortality and ambient air pollutant concentrations in Pittsburgh, Pennsylvania. J. Air Waste Manag. Assoc. 2000, 50, 1481-1500. [CrossRef]

240. Shields, K.N.; Cavallari, J.M.; Hunt, M.J.; Lazo, M.; Molina, M.; Molina, L.; Holguin, F. Traffic-related air pollution exposures and changes in heart rate variability in Mexico City: A panel study. Environ. Health $A$ Glob Access Sci. Source 2013, 12, 1-14. [CrossRef]

241. Ul-Saufie, A.Z.; Yahaya, A.S.; Ramli, N.A.; Rosaida, N.; Hamid, H.A. Future daily PM $_{10}$ concentrations prediction by combining regression models and feedforward backpropagation models with principle component analysis (PCA). Atmos. Environ. 2013, 77, 621-630. [CrossRef]

242. Popoola, O.A.M.; Carruthers, D.; Lad, C.; Bright, V.B.; Mead, M.I.; Stettler, M.E.J.; Saffell, J.R.; Jones, R.L. Use of networks of low cost air quality sensors to quantify air quality in urban settings. Atmos. Environ. 2018, 194, 58-70. [CrossRef]

243. Williams, R.; Kilaru, V.J.; Snyder, E.G.; Kaufman, A.; Dye, T.; Rutter, A.; Russell, A.; Hafner, H. Air Sensor Guidebook; Office of research and development (US EPA): Washington, DC, USA, 2014.

244. Williams, R. EPA Tools and Resources Webinar: Low Cost Air Quality Sensors; EPA National Exposure Research Laboratory (US EPA): Washington, DC, USA, 2019.

245. Wang, Z.; Delp, W.W.; Singer, B.C. Performance of low-cost indoor air quality monitors for $\mathrm{PM}_{2.5}$ and $\mathrm{PM}_{10}$ from residential sources. Build. Environ. 2020, 171, 106654. [CrossRef]

246. Clements, A.L.; Griswold, W.G.; Rs, A.; Johnston, J.E.; Herting, M.M.; Thorson, J.; Collier-Oxandale, A.; Hannigan, M. Low-cost air quality monitoring tools: From research to practice (A workshop summary). Sensors (Switzerland) 2017, 17, 2478. [CrossRef]

247. Sayahi, T.; Butterfield, A.; Kelly, K.E. Long-term field evaluation of the Plantower PMS low-cost particulate matter sensors. Environ. Pollut. 2019, 245, 932-940. [CrossRef] [PubMed]

248. Castell, N.; Dauge, F.R.; Schneider, P.; Vogt, M.; Lerner, U.; Fishbain, B.; Broday, D.; Bartonovaa, A. Can commercial low-cost sensor platforms contribute to air quality monitoring and exposure estimates? Environ. Int. 2017, 99, 293-302. [CrossRef] [PubMed]

249. Papapostolou, V.; Zhang, H.; Feenstra, B.J.; Polidori, A. Development of an environmental chamber for evaluating the performance of low-cost air quality sensors under controlled conditions. Atmos. Environ. 2017, 171, 82-90. [CrossRef]

250. Rai, A.C.; Kumar, P.; Pilla, F.; Skouloudis, A.N.; Di Sabatino, S.; Ratti, C.; Yasar, A.; Rickerby, D. End-user perspective of low-cost sensors for outdoor air pollution monitoring. Sci. Total Environ. 2017, 607-608, 691-705. [CrossRef] 
251. Malings, C.; Tanzer, R.; Hauryliuk, A.; Saha, P.K.; Robinson, A.L.; Presto, A.A.; Subramanian, R. Fine particle mass monitoring with low-cost sensors: Corrections and long-term performance evaluation. Aerosol. Sci. Technol. 2020, 54, 160-174. [CrossRef]

252. AQ-SPEC. Air Quality Sensor Performance Evaluation Center (AQ-SPEC) n.d. Available online: http: //www.aqmd.gov/aq-spec (accessed on 4 April 2020).

253. US-EPA. Air Sensor Toolbox; Evaluation of Emerging Air Pollution Sensor Performance. US-EPA n.d. Available online: https://www.epa.gov/air-sensor-toolbox/evaluation-emerging-air-sensor-performance (accessed on 4 April 2020).

254. Spinelle, L.; Gerboles, M.; Villani, M.G.; Aleixandre, M.; Bonavitacola, F. Field calibration of a cluster of low-cost available sensors for air quality monitoring. Part A: Ozone and nitrogen dioxide. Sensors Actuators B Chem. 2015, 215, 249-257. [CrossRef]

255. Spinelle, L.; Gerboles, M.; Villani, M.G.; Aleixandre, M.; Bonavitacola, F. Field calibration of a cluster of low-cost commercially available sensors for air quality monitoring. Part B: $\mathrm{NO}, \mathrm{CO}$ and $\mathrm{CO}_{2}$. Sensors Actuators B Chem. 2017, 238, 706-715. [CrossRef]

256. Polidori, A.; Papapostolou, V.; Zhang, H. Laboratory Evaluation of Low-Cost Air Quality Sensors; SCAQMD: Diamond Bar, CA, USA, 2016.

257. Goletto, V.; Mialon, G.; Faivre, T.; Wang, Y.; Lesieur, I.; Petigny, N.; Vijapurapu, S. Formaldehyde and total VOC (TVOC) commercial low-cost monitoring devices: From an evaluation in controlled conditions to a use case application in a real building. Chemosensors 2020, 8, 8. [CrossRef]

258. Taylor, M.D.; Nourbakhsh, I.R.; Steinfeld, A.; Presto, A.; Longhurst, J. Calibration and Characterization of Low-Cost Fine Particulate Monitors and their Effect on Individual Empowerment; The Robotics Institute Carnegie Mellon University: Pittsburgh, PA, USA, 2016; p. 146.

259. Giusto, E.; Gandino, F.; Greco, M.L.; Grosso, M.; Montrucchio, B.; Rinaudo, S. An investigation pervasive technologies for IoT-based thermal monitoring. Sensors (Switzerland) 2019, 19, 663. [CrossRef]

260. Budde, M.D.; Schwarz, A.; Müller, T.; Laquai, B.; Streibl, N.; Schindler, G.; Köpke, M.; Riedel, T.; Dittler, A.; Beig, M. Potential and Limitations of the Low-Cost SDS011 Particle Sensor for Monitoring Urban Air Quality. ProScience 2018, 5, 6-12. [CrossRef]

261. Polidori, A.; Papapostolou, V.; Feenstra, B.; Zhang, H. Field Evaluation of Low-Cost Air Quality Sensors Field Setup and Testing Protocol; The Robotics Institute Carnegie Mellon University: Pittsburgh, PA, USA, 2017.

262. AQ-SPEC. Aeroqual PM Sensor Evaluation Summary. n.d.; AQ-SPEC: Diamond Bar, CA, USA, 2019.

263. AQ-SPEC. Air Quality Egg Evaluation Summary; AQ-SPEC: Diamond Bar, CA, USA, 2019.

264. AQ-SPEC. Particle Sensor Dylos/DC1700-PM Evaluation Summary. n.d.; AQ-SPEC: Diamond Bar, CA, USA, 2019.

265. AQ-SPEC. Shinyei PM Sensor Evaluation Kit Summary. n.d.; AQ-SPEC: Diamond Bar, CA, USA, 2019.

266. AQ-SPEC. Field Evaluation Footbot Sensor. n.d.; AQ-SPEC: Diamond Bar, CA, USA, 2019.

267. AQ-SPEC. Model AQY v0.5 Evaluation; AQ-SPEC: Diamond Bar, CA, USA, 2019.

268. AQ-SPEC. Field Evaluation Air Quality Egg v.2 Ozone Sensor; AQ-SPEC: Diamond Bar, CA, USA, 2017.

269. AQ-SPEC. Field Evaluation Spec Gaseous Sensors; AQ-SPEC: Diamond Bar, CA, USA, 2019.

270. AQ-SPEC. Field Evaluation uHoo PM 2.5, Ozone, and CO Sensor; AQ-SPEC: Diamond Bar, CA, USA, 2019.

271. Manjunatha, P.; Verma, A.K.; Srividya, A. Multi-sensor data fusion in cluster based wireless sensor networks using fuzzy logic method. In Proceedings of the IEEE Region 10 Colloquium 3rd International Conference on Industrial and Information Systems ICIIS 2008, Kharagpur, India, 8-10 December 2008; pp. 1-6. [CrossRef]

272. Guo, L.; Wang, G.; Yu, X. Design for indoor environment monitoring system based on embedded system and multi-sensor data fusion algorithm. Int. J. Smart. Home 2016, 10, 31-40. [CrossRef]

273. Tang, M.; Wu, X.; Agrawal, P.; Pongpaichet, S.; Jain, R. Integration of Diverse Data Sources for Spatial PM 2.5 Data Interpolation. IEEE Trans. Multimed. 2017, 19, 408-417. [CrossRef]

274. Lin, Y.S.; Chang, Y.H.; Chang, Y.S. Constructing $\mathrm{PM}_{2.5}$ map based on mobile $\mathrm{PM}_{2.5}$ sensor and cloud platform. In Proceedings of the 2016 16th IEEE International Conference on Computer and Information Technology (CIT), Nadi, Fiji, 8-10 December 2016; pp. 702-707. [CrossRef]

275. Das, P.; Shrubsole, C.; Jones, B.; Hamilton, I.; Chalabi, Z.; Davies, M.; Mavrogiannia, A.; Taylora, J. Using probabilistic sampling-based sensitivity analyses for indoor air quality modelling. Build. Environ. 2014, 78, 171-182. [CrossRef] 
276. Kadiyala, A.; Kumar, A. An examination of the sensitivity of sulfur dioxide, nitric oxide, and nitrogen dioxide concentrations to the important factors affecting air quality inside a public transportation bus. Atmosphere (Basel) 2012, 3, 266-287. [CrossRef]

277. Rackes, A.; Ben-David, T.; Waring, M.S. Sensor networks for routine indoor air quality monitoring in buildings: Impacts of placement, accuracy, and number of sensors. Sci. Technol. Built. Environ. 2018, 24, 188-197. [CrossRef]

278. Kar, S.; Varshney, P.K. Accurate estimation of indoor occupancy using gas sensors. In Proceedings of the ISSNIP 2009-Proceedings of 2009 5th International Conference on Intelligent Sensors, Sensor Networks and Information Processing, Melbourne, VIC, Australia, 7-10 December 2009; pp. 355-360. [CrossRef]

279. Dai, X.; Liu, J.; Zhang, X. Monte Carlo simulation to control indoor pollutants from indoor and outdoor sources for residential buildings in Tianjin, China. Build. Environ. 2019, 165, 106376. [CrossRef]

Publisher's Note: MDPI stays neutral with regard to jurisdictional claims in published maps and institutional affiliations.

(C) 2020 by the authors. Licensee MDPI, Basel, Switzerland. This article is an open access article distributed under the terms and conditions of the Creative Commons Attribution (CC BY) license (http://creativecommons.org/licenses/by/4.0/). 